\title{
12. CONTROLS ON THE SEDIMENTARY AND SUBSIDENCE HISTORY OF AN ACTIVE PLATE MARGIN: AN EXAMPLE FROM THE TONGA ARC (SOUTHWEST PACIFIC) ${ }^{1}$
}

\author{
Peter D. Clift ${ }^{2}$
}

\begin{abstract}
Sedimentary sections recovered from the Tonga platform and forearc during Ocean Drilling Program Leg 135 provide a record of the sedimentary evolution of the active margin of the Indo-Australian Plate from late Eocene time to the Present. Facies analyses of the sediments, coupled with interpretations of downhole Formation MicroScanner logs, allow the complete sedimentary and subsidence history of each site to be reconstructed. After taking into account the water depths in which the sediments were deposited and their subsequent compaction, the forearc region of the Tofua Arc (Site 841) can be seen to have experienced an initial period of tectonic subsidence dating from $35.5 \mathrm{Ma}$. Subsidence has probably been gradual since that time, with possible phases of accelerated subsidence, starting at 16.2 and 10.0 Ma. The Tonga Platform (Site 840) records only the last 7.0 Ma of arc evolution. However, the increased accuracy of paleowater depth determinations possible with shallow-water platform sediments allows the resolution of a distinct increase in subsidence rates at $5.30 \mathrm{Ma}$. Thus, sedimentology and subsidence analyses show the existence of at least two, and possibly four, separate subsidence events in the forearc region.

Subsidence dating from 35.5 Ma is linked to rifting of the South Fiji Basin. Any subsidence dating from 16.2 Ma at Site 841 does not correlate with another known tectonic event and is perhaps linked to localized extensional faulting related to slab roll back during steady-state subduction. Subsidence from 10.0 Ma coincides with the breakup of the early Tertiary Vitiaz Arc because of the subduction polarity reversal in the New Hebrides and the subsequent readjustment of the plate boundary geometry. More recently, rapid subsidence and deposition of a upward-fining cycle from $5.30 \mathrm{Ma}$ to the Present at Site 840 is thought to relate to rifting of the Lau Basin. Sedimentation is principally controlled by tectonic activity, with variations in eustatic sea level playing a significant, but subordinate role. Subduction of the Louisville Seamount Chain seems to have disrupted the forearc region locally, although it had only a modest effect on the subsidence history and sedimentation of the Tonga Platform as a whole.
\end{abstract}

\section{INTRODUCTION}

The island-arc systems of the western Pacific have for many years been interpreted as the products of continuous subduction of oceanic lithosphere during the Cenozoic along the active margin of the Indo-Australian Plate. The tectonic histories of these arcs provide the best known modern examples of active plate margin deformation processes in a purely oceanic environment. Thus, deep drilling of the Tonga platform and forearc basin during Ocean Drilling Program (ODP) Leg 135 provided a unique opportunity to examine the sedimentary and tectonic responses to plate boundary interactions over a long period of time (approximately $40 \mathrm{Ma}$ ). This paper attempts to describe the sedimentary and subsidence history of both the Tonga platform and forearc basin and to relate these to the breakup of an original early Tertiary island arc and the opening of marginal basins by arc rifting processes.

Subduction of Pacific lithosphere along the plate boundary is known to have been continuous from at least as early as the Eocene, and possibly back into the Cretaceous, as suggested by the presence of Maastrichtian acidic arc volcanics sampled on the Lord Howe Rise (Shipboard Scientific Party, 1973). This original island-arc system, known as the Vitiaz Arc (Gill et al., 1984), formed a continuous feature stretching from the north island of New Zealand to the Philippines. The arc has subsequently undergone a number of rifting events related to the opening of backarc basins (e.g., South Fiji Basin; Karig, 1970), until its breakup in middle Miocene times, following the collision of the Ontong-Java oceanic plateau with the trench at this time and the reversal of subduction polarity along the New Hebrides section of the plate margin. Subduction polarity along the Tonga section has remained unchanged; since the middle Miocene, the arc has rifted again

\footnotetext{
${ }^{1}$ Hawkins, J., Parson, L., Allan, J., et al., 1993. Proc, ODP, Sci. Results, 135: College Station, TX (Ocean Drilling Program).

${ }^{2}$ Department of Geology and Geophysics, Grant Institute, The University of Edinburgh, West Mains Road, Edinburgh, EH9 3JW, Scotland.
}

to form the Lau Basin (e.g., Parson, Hawkins, Allan, et al., 1992). In addition, the Tonga Arc has come into collision with the Louisville Seamount Chain over the last $2.0 \mathrm{Ma}$. Thus, a sedimentary section recovered from the forearc and dating back to the upper Eocene should contain important information as to how the arc has responded to each of a series of tectonic events during this time span.

\section{TECTONIC SETTING OF THE DRILL SITES}

The two drill sites considered here are situated on the trench side of the presently active Tofua volcanic arc (Fig. 1). The first site, Site 840 , penetrated $597 \mathrm{~m}$ into the Tonga Platform, a thick, relatively undeformed sequence of carbonate and volcaniclastic sediments, thought to have been deposited on the remnants of an earlier island arc. Site 840 now lies at $750 \mathrm{~m}$ water depth. The sediments recovered from this site date back to $7.0 \mathrm{Ma}$ (upper Miocene) and so record the history of sedimentation directly adjacent to the island arc throughout the course of arc rifting and formation of the Lau Basin. In contrast, Site 841 , situated on the outer edge of the forearc basin, has recovered sediments from $605 \mathrm{~m}$ of strata directly overlying a rhyolitic volcanic arc complex of unknown age. Compared with the high sediment accumulation rates at Site 840 , Site 841 has a condensed sequence dating from the late Eocene ( $37.0 \mathrm{Ma})$ to the present day. Thus, Site 841 provides a longer term picture of the tectonic evolution of the island arc. Furthermore, although sediments on the Tonga platform have undergone late Miocene normal faulting, deformation since that time has been restricted to relatively mild normal faulting that has not disturbed the recovered section. On the other hand, Site 841 shows a multitude of small-scale normal and reverse faults; most importantly, the section is cut by two major normal faults. The lowermost fault, separating the rhyolitic arc complex from an upper Eocene shallowwater carbonate sequence, is responsible for the loss of an unknown quantity of pre-upper Eocene strata. A second fault, higher in the section, separates two upward-fining cycles of sedimentation and has resulted in the loss of much of the middle Miocene section. The 


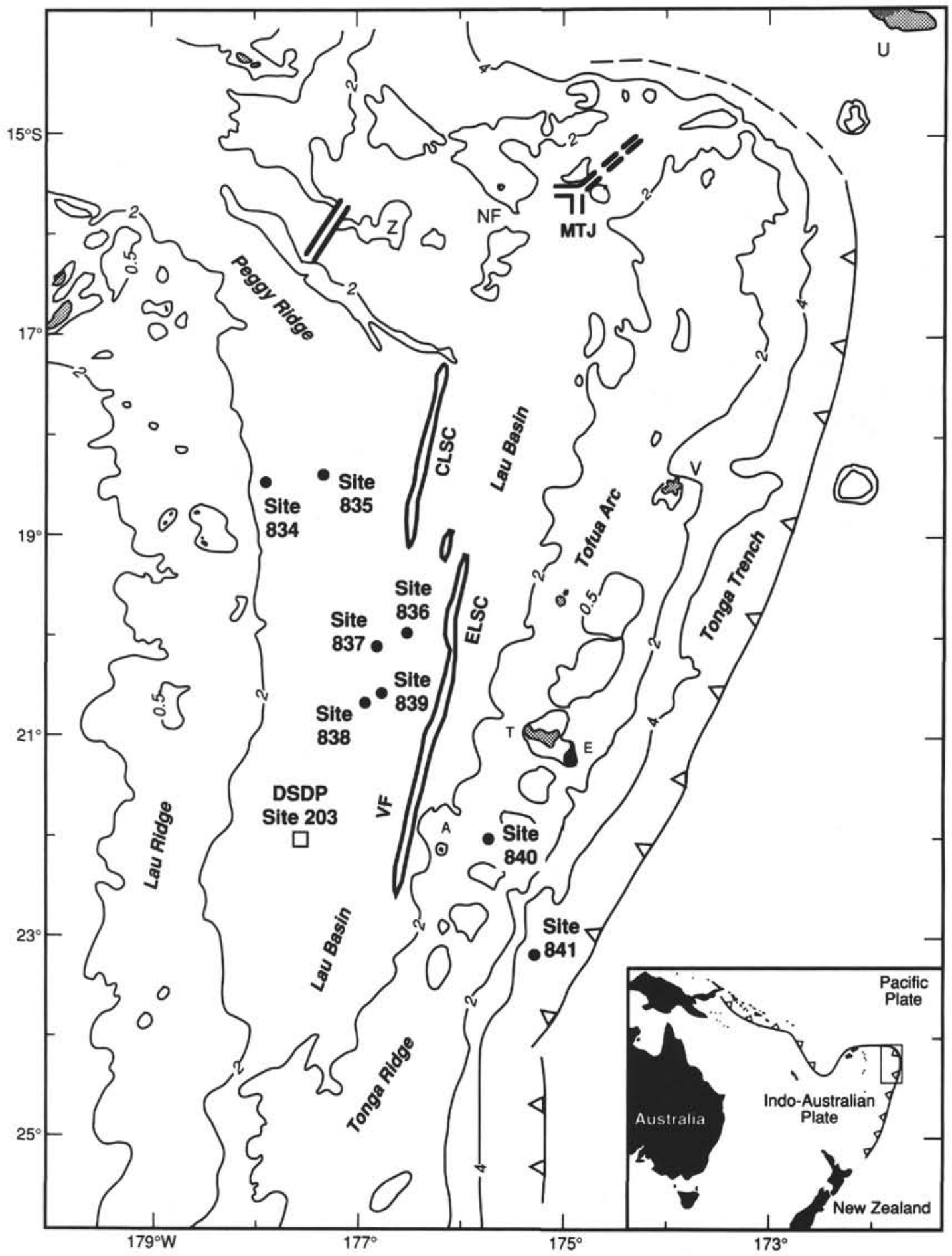

Figure 1. Location map showing the position of all sites from Leg 135, including Site 840 and Site 841 on the Tonga platform and outer edge of the forearc basin, trenchward of the presently active Tofua Arc. Bathymetry in kilometers. Line with triangles denotes plate boundary, with triangles on the overriding plate. $Z=$ Zephyr Shoal, MTJ = Mangatolu Triple Junction, NF = Niuafo'ou, CLSC $=$ Central Lau Spreading Center, ELSC $=$ Eastern Lau Spreading Center, VF = Valu Fa Ridge, $\mathrm{U}=$ Upolu, V = Vava'u, T $=$ Tongatapu, $\mathrm{E}=$ 'Eua, $\mathrm{A}=$ 'Ata, and $\mathrm{DSDP}=$ Deep Sea Drilling Project. 
presence of normal faulting from the base of the hole up to the seafloor at Site 841 indicates that the region is presently in active extension.

\section{SEDIMENTOLOGY}

In determining the sedimentary evolution of the Tonga Arc, the sediments at Sites 840 and 841 have been described by standard, on-board sedimentary logging, after which a preliminary facies analysis was made. In this study, the information derived from the cores has been enhanced by reference to the Formation MicroScanner (FMS) logs gathered at each site. An attempt has been made to construct a complete sedimentary log for each site using both sources of information. Critical to the FMS interpretation has been the ability to recognize sedimentary facies from their resistivity characteristics. This interpretation was considered necessary to improve confidence in the core-derived logs, many of which were based on rather low percentages of recovery ( $10 \%$ or less). Exact percentages of sediment recovery are given in the "Lithostratigraphy" sections of the reports for each site in the Leg 135 Initial Reports volume (Parson, Hawkins, Allan, et al., 1992). In particular, I hoped to check that the coring process had not preferentially recovered one lithology in cases of low core recovery, thereby producing a misleading picture of the sedimentary sequence for any one part of the section.

To determine lithologies and sedimentary structures, interpretations of the FMS traces were made with reference to criteria set out by Serra (1989). When reconstructing a sedimentary log from the FMS traces, interpretations were made with reference to the core descriptions for the intervals concerned, as recommended by Harker et al. (1990). The close interaction between core and FMS log was considered essential, because occasionally it was difficult to distinguish facies from the FMS logs alone. For instance, the FMS contrast of fine volcanic mudstone interbedded with volcanic siltstone or sandstone, such as those found at Sites 840 and 841 , appeared very similar to the FMS contrast of clayrich nannofossil ooze interbedded with volcanic sandstone (i.e., dark and light alternations in each case). The FMS interpretation of finegrained rocks such as these was based on brightness contrast in imaged lithologies, rather than on unique characteristics. Even in the case of conglomerates and breccias, which generally had a distinctive FMS texture, cross-checking with the core was necessary because bioturbation, such as that found in nannofossil chalk toward the top of Site 840, was seen to give a similar patchy pattern. In addition to the similarity of the FMS response from different facies, other factors such as brecciation caused by faulting and mineralization radically altered the appearance of some lithologies to FMS, making a unique interpretation of a given FMS log impossible. A good example of the effect of tectonic brecciation can be seen between 576.0 and 594.0 mbsf at Site 841, in which calcareous volcanic sandstones, normally showing distinct bedding and moderate to high resistances in FMS images, are seen to be disrupted and appear as massive, shattered lithologies of low resistance.

As an additional aid in cases of ambiguity, comparisons were made between FMS traces processed using a static normalization, which made up the bulk of the interpreted section, and traces with a dynamic normalization, as these often highlighted different features over the same interval of section. Normalization of the FMS images can be treated in two different ways. In the case of static normalization, a histogram of the resistivity data is constructed and the total range partitioned into a number of classes of equal size. Each class is represented by a different gray tone. The entire FMS section, therefore, is processed so that an equal amount of each of the gray tones exists on the final image. In the case of the dynamic normalization, the contrast in the FMS image is varied to enhance small differences in resistivity over sections that would otherwise appear uniform using the static normalization alone (Serra, 1989). Figures 2 and 3 illustrate the result of interpretations drawn up using the logging program of Waldron (1991), with sedimentary structures recognized in the FMS logs adjacent to the lithology recovered in the cores. Figure 4 presents representative pictures of the FMS images of the various sedimentary facies recognized.

\section{Site 840}

The sedimentary sequence drilled at Site 840 ranged in age back into the late Miocene. The core and FMS data both show a sequence of interbedded volcanic siltstones, sandstones, and conglomerates, together with nannofossil oozes and chalks (Fig. 2). The clastic sediments are typically medium-bedded $(10-100 \mathrm{~cm}$ thick) and display an overall tendency to fine upward from the base of the logged section (approximately $520.0 \mathrm{mbsf}$ ) to $258.0 \mathrm{mbsf}$, where a second cycle of sedimentation begins. These two cycles formed the basis of a three-part stratigraphy formulated during on-board sedimentary analysis, as the shipboard party split the upper cycle into two sections: a lower coarse-grained unit (II) and a higher fine-grained unit (I). The stratigraphic divisions made are also visible using the FMS logs. The break between the oldest and intermediate cycles of sedimentation (Units II and III) is clearly visible. However, the break between Units I and II (defined by the shipboard party as the point above which the volcaniclastic content of the sediment falls markedly) would seem to be placed rather lower in the sequence on the basis of the FMS logs and core, than with the core alone ( 128.5 vs. $109.9 \mathrm{mbsf})$. The disparity between the position of the contact of course merely reflects the nature of the recovery in this section of the hole.

The older cycle (Unit III) of sedimentation is wholly of upper Miocene age. The upward-fining trend is principally observed as the disappearance of conglomeratic beds and the marked reduction in the percentage (from $\sim 30 \%$ to $5 \%$ of the section) and thickness (from a maximum of $1.8 \mathrm{~m}$ to a minimum of $0.8 \mathrm{~m}$ ) of the sandstone beds. Toward the top of this first cycle, the sediments are dominated by volcanic siltstone and minor amounts of interbedded chalk. The FMS interpretation suggests that the apparent domination of the sequence by chalk over the top $50 \mathrm{~m}$ of this cycle ( $260-310 \mathrm{mbsf})$, as deduced from the core alone (which comprised $0 \%-80 \%$ chalk), may principally reflect the extremely poor recovery rates for this part of the section, often $10 \%$ or less. Instead, the FMS logs provided strong indications from the contrasting resistivity patterns that siltstone is the principle lithology over this depth range (Fig. 2).

Above $258.0 \mathrm{mbsf}$, a second upward-fining cycle (Units I and II) was recognized. These sediments accumulated from the upper Miocene to early Pliocene and, like the unit below, comprise sharp-based, graded volcaniclastic sediments within a background of nannofossil chalk beds. Compared with the lower sedimentary cycle, the bedding, particularly of the volcanic conglomerates, is very much thicker, with beds over $13 \mathrm{~m}$ thick. The proportion of conglomerate in the sequence is also considerably higher, although it decreases rapidly above 128.0 mbsf (upper lower Pliocene), giving way to a carbonate-dominated sequence, with minor interbedded sands and silts, in which bioturbation is pervasive. Interestingly, no significant change seems to have occurred in the nature of the sedimentation at $383.0 \mathrm{mbsf}$, which was identified as the regional unconformity (the "A-Horizon") of Austin et al. (1989), on the basis of downhole logging information (Parson, Hawkins, Allan, et al., 1992).

\section{Site 841}

The sedimentology of Site 841 is clearly displayed by the interpreted sedimentary log shown in Figure 3. Of the five lithologic subdivisions made during on-board analyses, the four oldest subdivisions (Units V-II) logged are distinguishable using the FMS traces. Although the normal faulted base of the lowermost, upper Eoceneupper Oligocene unit (Unit V) is not clearly shown by the FMS images, the massive carbonates with large neritic foraminifers of this unit are visible on the FMS logs (607.0-596.3 mbsf). As shown in both core and FMS data, the sequence then passes up into a thick-bed- 

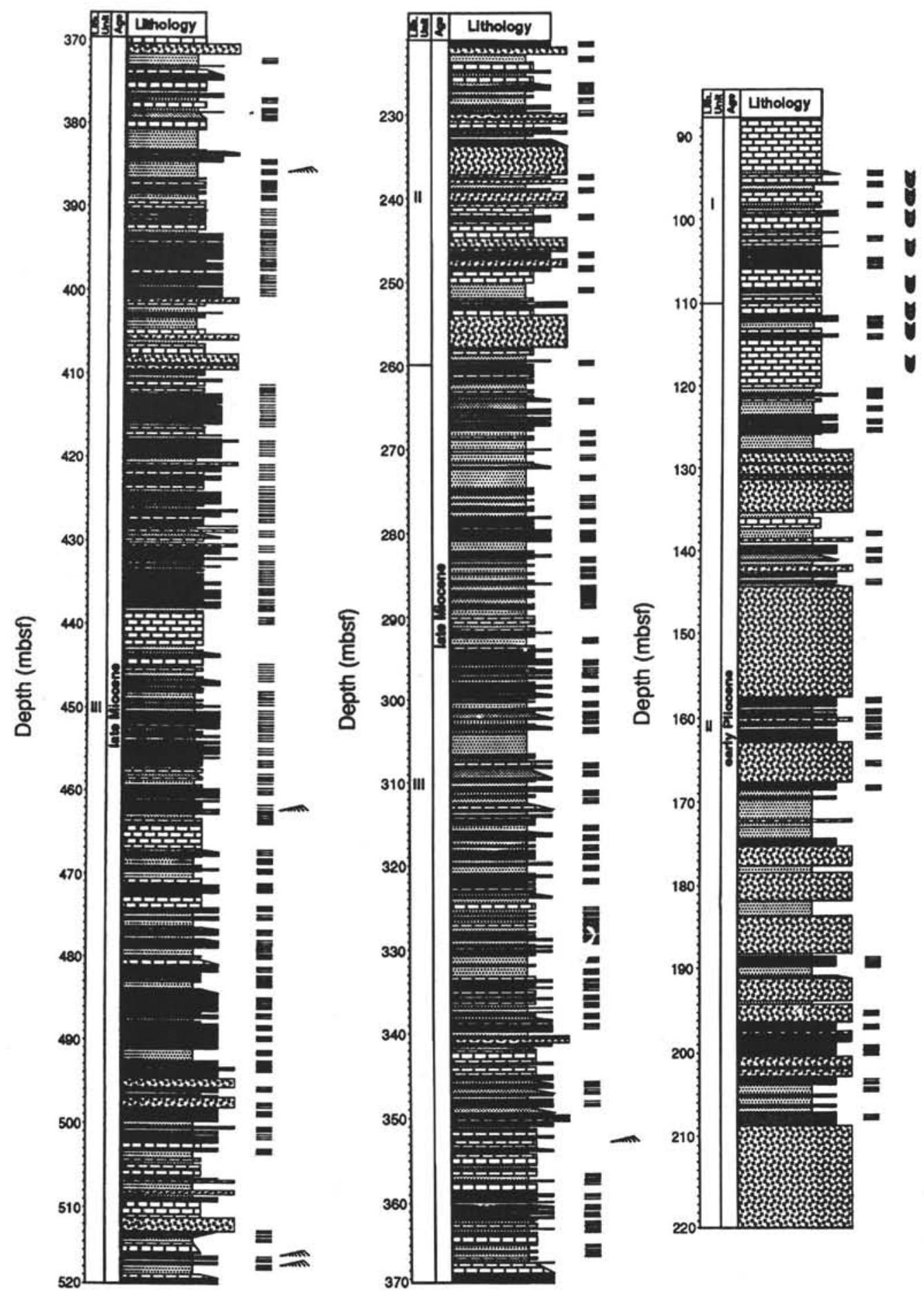

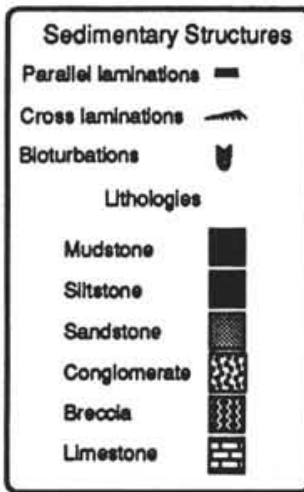

Tonga Platform, Site 840

Figure 2. Sedimentary log of the sedimentary sequence drilled at Site 840 constructed by interpretation of FMS logging data and comparison with cores.

ded, volcanic sand-dominated series (576.0-549.1 mbsf), with variable minority quantities of carbonate debris, a feature not discernible with the FMS, unlike the common parallel and cross laminations, which indicate a current-deposited origin for these rocks. The presence of a long-lived unconformity ( $549.1 \mathrm{mbsf}$ ), which marks the top of the basal sedimentary unit (Unit V), is difficult to identify on the FMS logs because of the presence of sandstones, dominated by volcanic debris, both above and below.

The sedimentology of the lower middle Miocene unit (Unit IV; 463.1-549.1 mbsf), lying above the break, is clearly an upward-fining sequence of proximal to distal turbidites ending abruptly in a second strongly brecciated and easily identifiable fault zone (461.2-463.1 mbsf; Fig. 3). Although medium- to thick-bedded, parallel- and cross-laminated sandstones and conglomerates dominate the bottom $10-15 \mathrm{~m}$ of this unit, these give way to a sequence dominated by siltstones with minor interbedded shales and sandstones. Large thicknesses of siltstone are marked by a number of features, including slump folds, water-escape structures, and parallel and cross laminations, testifying to the catastrophic nature of their deposition. In addition, faulting and the disruptive effects of mineralization, identi- 

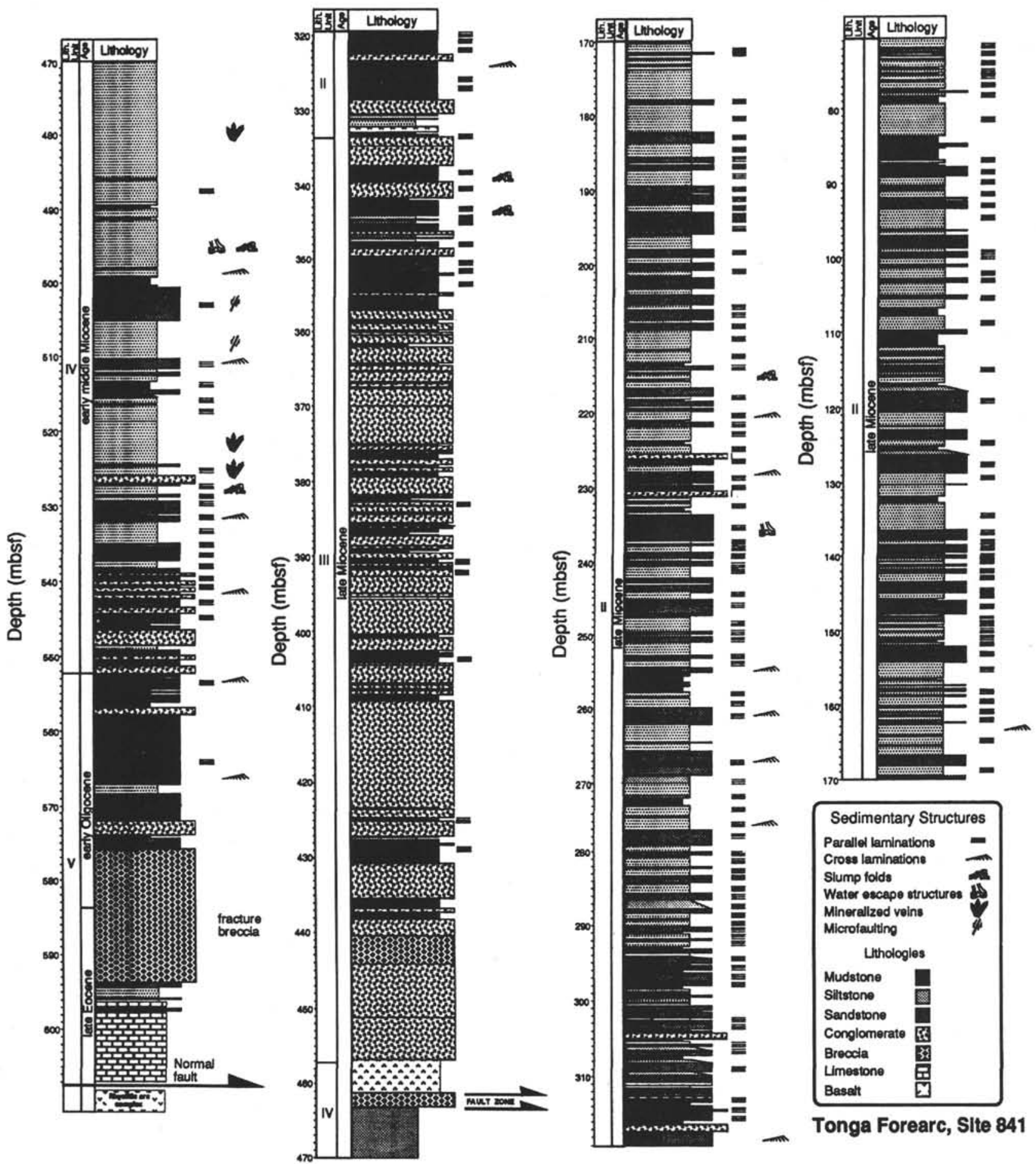

Tonga Forearc, Slte 841

Figure 3. Sedimentary log of the sedimentary sequence drilled at Site 841 constructed by interpretation of FMS logging data and comparison with cores.

fied in the core, were also recognized within the otherwise monotonous siltstone lithologies recorded by the FMS logs.

The FMS logs indicate that the top two units defined by the shipboard party (Units II and III) form two halves of a second upward-fining cycle of late Miocene age. The basal $4.3 \mathrm{~m}$ of the unit has been intruded by one of a number of basaltic dikes, which remains outside the scope of this paper. The basal $100 \mathrm{~m}$ of this upper unit $(456.8-357.0 \mathrm{mbsf})$ is seen to be hugely dominated (>90\%) by thick-bedded conglomerates (as much as $14 \mathrm{~m}$ thick) that show little in the way of sedimentary structures, except for rare parallel laminae. These sediments are thought to be the result of deposition from proximal turbidites, although they reveal little grading except along their top contact, where they often pass rapidly up into the mediumbedded sandstones that separate individual conglomeratic beds. The division between the conglomeratic lower unit (III) and the sandy upper unit (II) of the shipboard stratigraphy was defined arbitrarily at $333.0 \mathrm{mbsf}$, a depth that correlates well with the same transition in the FMS log. Upsection, a 40-m-thick, sandstone-dominated section passes into a medium- to thick-bedded, siltstone-sandstone succession. The sedimentary log shows an increase in the proportion of mudstone toward the top, with a significant proportion (approximately $15 \%$ ) of the top $50 \mathrm{~m}$ of the section ( $70-120 \mathrm{mbsf}$ ) composed 


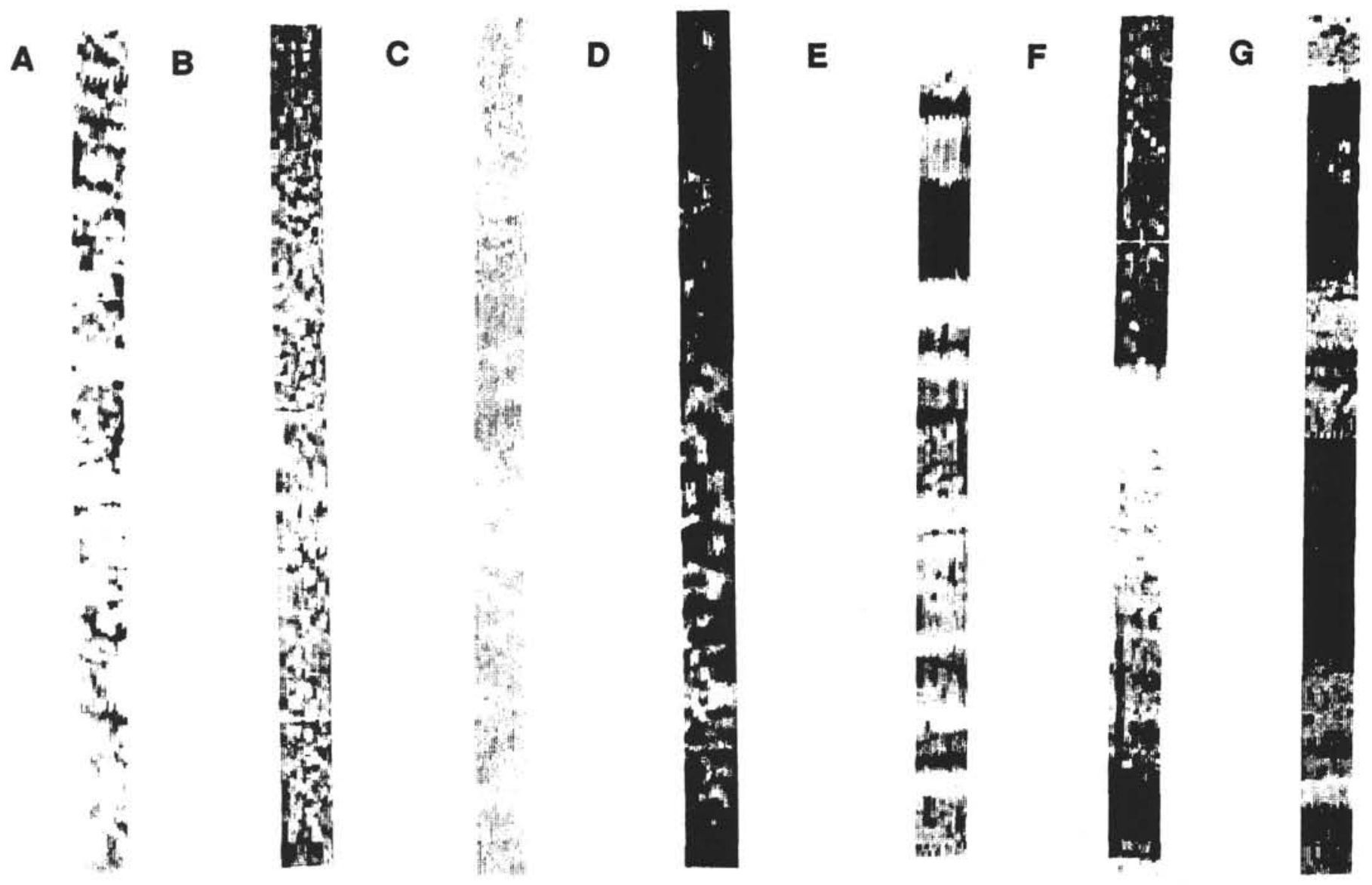

Figure 4. FMS images of the sedimentary facies identified at Sites 840 and 841 . A. Graded conglomerate (254.4-255.4 mbsf, Hole 840B). B. Coarse, unsorted conglomerate (413.2-414.2 mbsf, Hole 841C). C. Foraminifer-rich limestone (598.6-598.6 mbsf, Hole 841C). D. Bioturbated chalk (115.0-116.2 mbsf, Hole 840 B). E. Parallel-laminated siltstone and sandstone (301.2-302.2 mbsf, Hole 840B). F. Siltstone grading up into sandstone, overlain by conglomerate (498.2-499.2 mbsf, Hole 840B). G. Graded siltstone interbedded with mudstone (390.8-391.8 mbsf, Hole 840B). All specimens are shown with static normalization.

of this lithology. Sedimentary structures recognized in this upper cycle include numerous parallel laminations with minor amounts of cross-lamination, slump folds, and rare water-escape structures, consistent with the proposed mode of deposition from turbidity currents.

\section{SUBSIDENCE ANALYSIS}

Having made a facies analysis of the sediments from each site, it is now possible to suggest environments of deposition and thus make paleowater depth determinations. Using these estimates, together with the thicknesses and certain physical properties of the sediments concerned (i.e., density, porosity, and rate of compaction on burial), the rate and amount of tectonic subsidence of the basement at each drill site may be calculated through the use of sedimentary backstripping techniques. Subsidence was determined using the initial criteria of Sclater and Christie (1980) and taking into account the loading of water and sediment on the basement. The calculation is performed by removing each dated sedimentary layer, allowing the sediments below to decompact after its removal, and then restoring the sediment package to the paleowater depth determined by sedimentary analysis. In this reconstruction, the compaction of each sediment type with burial and water loading is assumed to follow the trend defined by Sclater and Christie (1980). Sclater and Christie's analysis was constructed for rather shallower water depths $(<500 \mathrm{~m})$, which may lead to minor errors in the case of Site 841, where the water loading is so much greater. Differences in the degree of compaction at such water depths probably result in an additional error of no more than $5 \%$ (J. Turner, pers. comm., 1992).

Calculation of the loading effects of water and sediment on the basement permits the tectonically driven subsidence of the basement at each site to be determined. Fundamental to this calculation is the assumption of Airy isostasy. Although the tectonic complexity of this active margin setting would seem to make this a dubious assumption, structural evidence from the core indicates that for much of the subsidence history both Sites 840 and 841 were in active extension, therefore justifying a simple isostatic assumption. The presence of small-scale compressional structures in some parts of the core from Site 841 is considered to be a record of the deformation of the forearc caused by the subduction of the Louisville Seamount Chain in the middle Pleistocene. This passing event seems to have had only a brief effect on the subsidence history of the forearc, presumably causing it to be uplifted during passage of the ridge through the area. In the case of Site 840, the Airy isostatic condition would seem to be more easily met, because only extensional structures were observed in the core, together with large-scale normal faults (Austin et al., 1989) identified close to Site 840 on seismic sections of the platform.

\section{PALEOWATER DEPTHS}

\section{Site 840}

Another important constraint in the subsidence calculation is that of paleowater depth. Without the constraint of paleowater depths, 
Table 1. Data of sedimentary thickness, lithologies, ages, and interpreted paleowater depths for Sites 840 and 841 used for the subsidence analysis calculation.

\begin{tabular}{|c|c|c|c|c|c|c|c|}
\hline $\begin{array}{c}\text { Depth to } \\
\text { base of } \\
\text { interval }(\mathrm{m})\end{array}$ & $\begin{array}{c}\text { Depth to } \\
\text { top of } \\
\text { interval }(\mathrm{m})\end{array}$ & $\begin{array}{c}\text { Age } \\
\text { at base } \\
(\mathrm{Ma})\end{array}$ & $\begin{array}{l}\text { Age } \\
\text { at top } \\
(\mathrm{Ma})\end{array}$ & $\begin{array}{c}\text { Paleowater } \\
\text { depth }(m)\end{array}$ & Lithology & $\begin{array}{l}\mathrm{CCD} \\
\text { depth } \\
\text { (m) }\end{array}$ & $\begin{array}{l}\text { Lysocline } \\
\text { depth } \\
\text { (m) }\end{array}$ \\
\hline \multicolumn{8}{|c|}{ Site 840 (Model A, shallow-water): } \\
\hline 752.5 & 743.0 & 0.50 & 0.40 & 740 & Chalk & 4400 & 3900 \\
\hline 771.4 & 752.5 & 1.80 & 1.70 & $300-600$ & Chalk & 4300 & 3800 \\
\hline 780.9 & 771.4 & 1.90 & 1.80 & $300-600$ & Chalk & 4300 & 3800 \\
\hline 800.0 & 780.9 & 2.65 & 1.90 & $300-600$ & Sandstone & 4200 & 3700 \\
\hline 819.0 & 800.0 & 3.00 & 2.65 & $300-600$ & Sandstone & 4200 & 3700 \\
\hline 838.7 & 819.4 & 3.50 & 3.10 & $300-600$ & Chalk & 4100 & 3600 \\
\hline 848.4 & 838.7 & 4.90 & 4.50 & $300-600$ & Chalk & 4100 & 3600 \\
\hline 935.0 & 848.4 & 5.20 & 4.90 & $300-600$ & Conglomerate/sandstone & 4000 & 3500 \\
\hline 1002.7 & 935.0 & 5.25 & 5.20 & $300-600$ & Conglomerate/sandstone & 4000 & 3500 \\
\hline 1031.8 & 1002.7 & 5.30 & 5.25 & $300-600$ & Sandstone & 4000 & 3500 \\
\hline 1041.5 & 1031.8 & 5.60 & 5.30 & $300-600$ & Chalk & 4000 & 3500 \\
\hline 1070.5 & 1041.5 & 5.80 & 5.60 & $300-600$ & Siltstone & 4000 & 3500 \\
\hline 1166.9 & 1070.5 & 6.50 & 5.80 & $300-600$ & Siltstone/chalk & 4000 & 3500 \\
\hline 1340.3 & 1166.9 & 7.10 & 6.50 & $300-600$ & Sandstone & 4000 & 3500 \\
\hline \multicolumn{8}{|c|}{ Site 840 (Model B, deep-water): } \\
\hline 752.5 & 743.0 & 0.50 & 0.40 & 740 & Chalk & 4400 & 3900 \\
\hline 771.4 & 752.5 & 1.80 & 1.70 & $300-600$ & Chalk & 4400 & 3800 \\
\hline 780.9 & 771.4 & 1.90 & 1.80 & $300-600$ & Chalk & 4300 & 3800 \\
\hline 800.0 & 780.9 & 2.65 & 1.90 & $300-600$ & Sandstone & 4200 & 3700 \\
\hline 819.0 & 800.0 & 3.00 & 2.65 & $300-600$ & Sandstone & 4200 & 3700 \\
\hline 838.7 & 819.4 & 3.50 & 3.10 & $300-600$ & Chalk & 4100 & 3600 \\
\hline 848.4 & 838.7 & 4.90 & 4.50 & $300-600$ & Chalk & 4100 & 3600 \\
\hline 935.0 & 848.4 & 5.20 & 4.90 & $300-600$ & Conglomerate/sandstone & 4000 & 3500 \\
\hline 1002.7 & 935.0 & 5.25 & 5.20 & $300-600$ & Conglomerate/sandstone & 4000 & 3500 \\
\hline 1031.8 & 1002.7 & 5.30 & 5.25 & $300-600$ & Sandstone & 4000 & 3500 \\
\hline 1041.5 & 1031.8 & 5.60 & 5.30 & $1500-3500$ & Chalk & 4000 & 3500 \\
\hline 1070.5 & 1041.5 & 5.80 & 5.60 & $3500-4000$ & Siltstone & 4000 & 3500 \\
\hline 1166.9 & 1070.5 & 6.50 & 5.80 & $3500-4000$ & Siltstone/chalk & 4000 & 3500 \\
\hline 1340.3 & 1166.9 & 7.10 & 6.50 & $3500-4000$ & Sandstone & 4000 & 3500 \\
\hline \multicolumn{8}{|l|}{ Site 841: } \\
\hline 5426.0 & 5413.9 & 37.50 & 37.30 & $0-100$ & Chalk & 3400 & 2900 \\
\hline 5413.9 & 5370.1 & 37.30 & 35.50 & $100-2700$ & Sandstone & 3200 & 2700 \\
\hline 5370.1 & 5366.0 & 35.50 & 35.00 & $2700-3200$ & Sandstone & 3700 & 3200 \\
\hline 5366.0 & 5269.5 & 16.20 & 14.90 & $1000-3800$ & Sandstone & 4300 & 3800 \\
\hline 5269.5 & 5096.6 & 10.00 & 9.00 & $3900-4200$ & Sandstone & 3900 & 3400 \\
\hline 5096.6 & 4886.5 & 9.00 & 5.30 & $4200-4500$ & Sandstone & 4200 & 3700 \\
\hline 4886.5 & 4821.0 & 5.30 & 0.00 & 4800 & Shale & 4300 & 3800 \\
\hline
\end{tabular}

Notes: Two sets of data exist for Site 840 , the first being the preferred scenario of consistent moderate water depths and the second indicating greater water depths during the Miocene. $\mathrm{CCD}=$ carbonate compensation depth.

deposition of large thicknesses of sediment over a given time span may equally reflect rapid subsidence or infilling of a preexisting basin. Table 1 includes the estimated paleowater depths for sediments from Sites 840 and 841 , including two possible sets of paleowater depths for Site 840 (Models A and B). In the case of Model A at Site 840 , the presence of abundant trace fossils and benthic foraminifers within the nannofossil chalks throughout the section cored is thought to indicate that the Tonga platform has remained at effectively the same depth with regard to sea level since the early late Miocene (i.e., $755 \mathrm{~m}$ ). The presence of Planolites sp., Thalassinoides sp., Zoophy$\cos \mathrm{sp}$. and Chondrites sp. in pelagic chalks is taken to indicate that the platform has always lain in relatively deep water well below the storm-wave base (Ekdale et al., 1984), at approximately $100 \mathrm{~m}$. The assemblage of trace fossils found at Site 840 is considered to be typical of the Zoophycos ichnofacies as defined by Seilacher (1963). This is generally found in and around the shelf break (i.e., $300-600 \mathrm{~m}$ ) during the late Cenozoic. Thalassinoides sp. is especially important in restricting water depths to being shallower than $600 \mathrm{~m}$ throughout the section cored, as other members of the ichnofacies are known over a wide water depth range. That water depths at Site 840 were never much shallower than they are today is also demonstrated (1) by a lack of typical shallow-water fauna and ichnofacies, and (2) by the absence of wave-generated sedimentary structures within the interbedded volcaniclastic lithologies.

Model B paleowater depths are derived from observations (J. Ledbetter (pers. comm. and unpubl. data, 1992) of partially dissolved nannofossils within pelagic chalk intervals from below $260 \mathrm{mbsf}$ in Site 840 . These sediments are of upper Miocene age. Although a number of factors may cause dissolution of nannofossils, this may indicate deposition in water depths within the lysocline. Van Andel (1975) estimated that during the late Miocene the carbonate compensation depth (CCD) lay at $4000 \mathrm{~m}$ in the Pacific. Berger and Winterer (1974) further indicated that the lysocline is approximately $500 \mathrm{~m}$ shallower than the CCD in the modern equatorial Pacific. Assuming a similar difference in depth between the lysocline and $\mathrm{CCD}$ during the late Miocene, Ledbetter's observation may imply that Site 840 then lay at 3500-4000 $\mathrm{m}$ water depth (Model B; Table 1). Possible complexities to this straightforward interpretation include whether the assumed depth of the late Miocene lysocline is approximately correct or not. Van Andel's (1975) estimate for the Pacific CCD could conceivably be invalid in the Tonga region, or the thickness between the CCD and the lysocline could be greater than the $500 \mathrm{~m}$ estimated. A possible reason for this could be the establishment of upwelling along the Tonga Trench by cold Antarctic bottom water during the late Miocene (Wise, 1981). This in turn would cause the CCD and the lysocline to rise above the normal Pacific depth and cause the observed corrosion.

However, assuming that the $3500-4000 \mathrm{~m}$ estimate for a zone of calcite dissolution is approximately correct, a number of factors suggest that Site 840 is unlikely to have been at this depth during the late Miocene. Apart from the trace fossil evidence mentioned above, the presence of abundant, uncorroded, shallow-water foraminifers within intercalated volcanic sandstones below $260 \mathrm{mbsf}$ is important in demonstrating that paleowater depths at Site 840 were relatively shallow. Although the sands are undoubtedly redeposited, the presence of shallow-water foraminifers requires that a shallow platform area be situated close by. Site 840 appears to have been structurally high on the Tonga platform throughout the time period concerned, so that if this high point was submerged to great depths during the 
Miocene then it is reasonable to expect that other potential source areas for the foraminifers would also have been submerged. If that had occurred, then the presence of the foraminifers is hard to explain. Theoretically, other regions of the Tonga platform might have been structurally higher at this time; however, this is thought to be unlikely. If such paleohighs had remained as highs, then they would have been elevated far above sea level when Site 840 was uplifted from lysocline depths to modern water depths in the uppermost Miocene. The considerable unconformity that would have been formed has not been recognized in the seismic lines of the platform (e.g., Austin et al., 1989). Any differential tectonic motion between Site 840 and a possible source area can also be discounted on the basis of the seismic data, which show a simple tilting of the entire Tonga platform since the late Miocene. Dip data from Site 840 (Parson, Hawkins, Allan, et al., 1992) also argue against any major uplift or subsidence events; instead, they support the idea of a gradual tilting and subsidence of the Tonga platform.

The corrosion of foraminifers and nannofossils is in any case not uniform within the core. Although dissolution is generally stronger lower in the core, exceptions exist in which well-preserved nannofossils are found (e.g., Samples 135-840B-33X-1, 75-76 cm, -34X-1, 90-91 cm, -39X-CC, -56X-CC, -58X-CC, and -61X-CC (P. Quinterno, pers. comm., 1992). If Site 840 truly lay within the lysocline at this time, then the presence of these fresh nannofossils is difficult to explain.

Thus, the weight of the evidence would indicate that water depths on the Tonga platform remained approximately constant throughout the time interval cored (late Miocene-Holocene), that is, at approximately $300-600 \mathrm{~m}$ (Model A). The dissolution of microfossils deep in the core at Site 840 is thought to be the result of diagenetic solution with burial. Preferential dissolution in pelagic chalks rather than volcanic sands would reflect the greater compaction and dissolution of a fine-grained lithology, compared to a grain-supported clastic sediment, as seen in sedimentary sequences worldwide. Nevertheless, in the following analysis of subsidence, both shallower (Model A; Table 1) and deeper (Model B; Table 1) water depths are considered for the Miocene and implications for each scenario discussed.

\section{Site 841}

Water depths at Site 841 have proved to be more difficult to estimate because of the variety of facies recognized and the large range in their possible depths of deposition. Estimated paleowater depths for Site 841 are displayed in Table 1. The presence of subaerial ignimbrites lying tectonically below the oldest marine rocks of the sampled section (upper Eocene carbonates) indicates an initial elevation of the basement above sea level, although the exact time of eruption is as yet unclear. Following this, the deposition of foraminifer-bearing volcanic sands and limestones closely constrains the paleowater depth to be within the photic zone (i.e., 0-100 m; Tucker and Wright, 1991) during the late Eocene (37.5-37.3 Ma). Reworking of shallow-water material into deep water can be ruled out as the benthic foraminifers, Discocyclina sp., are extremely flat and delicate and would be quickly broken and smashed during redeposition, which was not observed. In addition, the lack of pelagic intervals and the ripple-laminated, ungraded sandstones are suggestive of deposition in a current-swept shelf environment and not of redeposition by turbidity currents or mass flow. Going upsection into the lower Oligocene (37.3-35.5 Ma), the microfossil assemblage indicates a progressive decrease in the abundance of shallow-water species and an increase in pelagic species. Above Core 135-841B-42R (i.e., 35.5-35.0 Ma, lower Oligocene), the dissolution of nannofossils indicates that water depths had increased so that the site then lay within the lysocline, which was at approximately $3000 \mathrm{~m}$ during the Oligocene (van Andel, 1975). Paleowater depths are estimated at $2700-3200 \mathrm{~m}$ during $35.5-35.0 \mathrm{Ma}$, to allow for the very rapid deepening of the $\mathrm{CCD}$ and lysocline recorded over this time period. Paleowater depths for the intervening period of from 37.3 to
35.5 $\mathrm{Ma}$ are more difficult to estimate, but they must be intermediate between the units above and below (i.e., 100-2700 m).

A major unconformity separates these rocks from the overlying middle Miocene volcaniclastic sediments and may indicate a period of mass wasting and nondeposition. Clearly, water depths during the period of the unconformity (35.0-16.2 Ma; early Oligocene-middle Miocene) cannot be determined. Above the unconformity, water depths are difficult to constrain accurately on the basis of the sedimentary facies alone, as they are mass flow conglomerates, turbidites, or pelagic mudstones. The sequence of middle Miocene volcaniclastic mass flows immediately above the unconformity is marked by a well-preserved pelagic microfossil assemblage, consistent with deposition above the lysocline. By the middle Miocene, the lysocline had deepened significantly compared with its level during the Oligocene, reaching approximately $3800 \mathrm{~m}$. The upper limit of deposition is more difficult to constrain, with water depths as shallow as $1000 \mathrm{~m}$ being consistent with available microfossils. However, although a major uplift may have occurred during the period of the unconformity, the switch from deposition below the lysocline in the early Oligocene to deposition above the lysocline in the middle Miocene can be attributed to a simple deepening of the lysocline. That such an uplift is unlikely to have occurred is suggested by the structural information. Dip measurements indicate that much of the history of Site 841 is marked by a gradual tilting of the site toward the trench (MacLeod, this volume). These data argue against any major uplift between 35.0 and 16.2 Ma. This, in turn, strengthens the case for paleowater depths being close to the deep end of the $1000-3800 \mathrm{~m}$ range possible between 16.2 and 14.9 Ma (middle Miocene), as Site 841 had already subsided to approximately $3000 \mathrm{~m}$ by the start of the unconformity.

Sedimentation since 14.9 Ma is difficult to constrain in terms of paleowater depth. Removal of a section because of the large normal fault at 458.0 mbsf means that no data is available for the time period 14.9-10.0 Ma (middle to late Miocene). Between 10.0 and $9.0 \mathrm{Ma}$ (i.e., 448.5-275.6 mbsf), strong corrosion of calcareous nannofossils can be attributed to deposition close to or below the CCD, which lay at approximately $3900 \mathrm{~m}$ at $10.0 \mathrm{Ma}$ (van Andel, 1975). However, between 10.0 and $9.0 \mathrm{Ma}$, a rapid drop in the depth of the CCD occurred (to $4200 \mathrm{~m}$ ), associated with a rapid fall in eustatic sea level (Haq et al., 1987). Importantly, the nannofossils present over this part of the section (275.6-65.4 mbsf) remain strongly corroded, implying that Site 841 must also have undergone a similar degree of subsidence over the same time span for it to remain close to the CCD. Thus, from 9.0 to $5.3 \mathrm{Ma}$, a paleowater depth of $4200-4500 \mathrm{~m}$ is considered appropriate. Finally, the point in the section above which calcareous microfossils are no longer observed can also be used to constrain paleowater depth. This occurs at $65.4 \mathrm{mbsf}$, corresponding to an age of $5.3 \mathrm{Ma}$ (latest Miocene), a time when the CCD was at a depth of $4200 \mathrm{~m}$. Since $5.3 \mathrm{Ma}$, no constraint on paleowater depth is present, as the site then subsided below the CCD. Thus, the final water-depth constraint is the present-day depth of $4800 \mathrm{~m}$.

\section{SEA LEVEL}

The subsidence curves determined from the sediment thicknesses, lithologies, and paleowater depths have been calculated relative to present-day sea level. A number of authors in the past have attempted to reconstruct variations in global sea level through geologic time through the use of a number of techniques, including seismic stratigraphic onlap and offlap patterns (e.g., Vail et al., 1977; Haq et al., 1987) and calculations involving the volume of the world's mid-ocean ridge systems (e.g., Hallam, 1984). These models have predicted large-scale fluctuations in sea level (up to $>400 \mathrm{~m}$ ) and might be expected to affect adversely subsidence patterns that have been calculated with reference to paleowater depth. Recent work, however, has cast doubt on the reliability of such curves (e.g., in the upper Jurassic; Underhill, 1991). Although late Tertiary sea-level fluctua- 
tions are better known in terms of timing, the magnitude of sea-level rises and falls remains controversial. In addition, subsidence curves that have been corrected for these effects often show kinks in their trends (e.g., Wood, 1982) that do not readily fit present models of basin formation (e.g., McKenzie, 1978; White and McKenzie, 1988). Because of the unreliability of present knowledge on sea-level movement, much of the following discussion will focus on subsidence curves with no correction for sea-level fluctuations. However, a number of selected subsidence curves will also be shown with sealevel corrections that have been determined by using the curve of Haq et al. (1987).

\section{Subsidence History-Site 840}

Using the sediment thicknesses, ages, and paleowater depths described in Table 1, the subsidence of the basement at each site was calculated following the methods of Sclater and Christie (1980) using the program of Condon (1988; Tables 2-3). Figures 5A-5D show the calculated subsidence curves for Site 840 . Figure 5B corresponds to the favored subsidence history, in which water depths were comparable to modern values throughout the subsidence history (Model A), whereas Figure $5 \mathrm{C}$ corresponds to the alternative paleowater depth history (Model B), with its increased water depths in the late Miocene, as discussed above. Figure 5A shows two different profiles, one corrected for sediment unloading and another in which subsidence has taken into account the decompaction of the sediments, but without any regard for paleowater depth. This latter curve has a similar form to Figure 5B, in which the two curves show a correction for sediment decompaction and paleowater depth (both maximum and minimum). The similarity between Figures $5 \mathrm{~A}$ and $5 \mathrm{~B}$ is because according to Model A at Site 840 , sedimentation has broadly kept pace with subsidence. From the base of the cored section, dated at approximately $7.1 \mathrm{Ma}$, rapid subsidence was already under way. The first marked change in this profile comes at $5.3 \mathrm{Ma}$, when subsidence rates increase to $739 \mathrm{~m} / \mathrm{m}$.y., staying high until $4.9 \mathrm{Ma}$, after which they show a decrease with time (Fig. 6A). A subsidence/age diagram (Fig. 7A), constructed to show the progressive sedimentary accumulation at Site 840 , also clearly shows the jump in subsidence and accumu-

Table 2. Calculated subsidence data for Sites 840 and 841 .

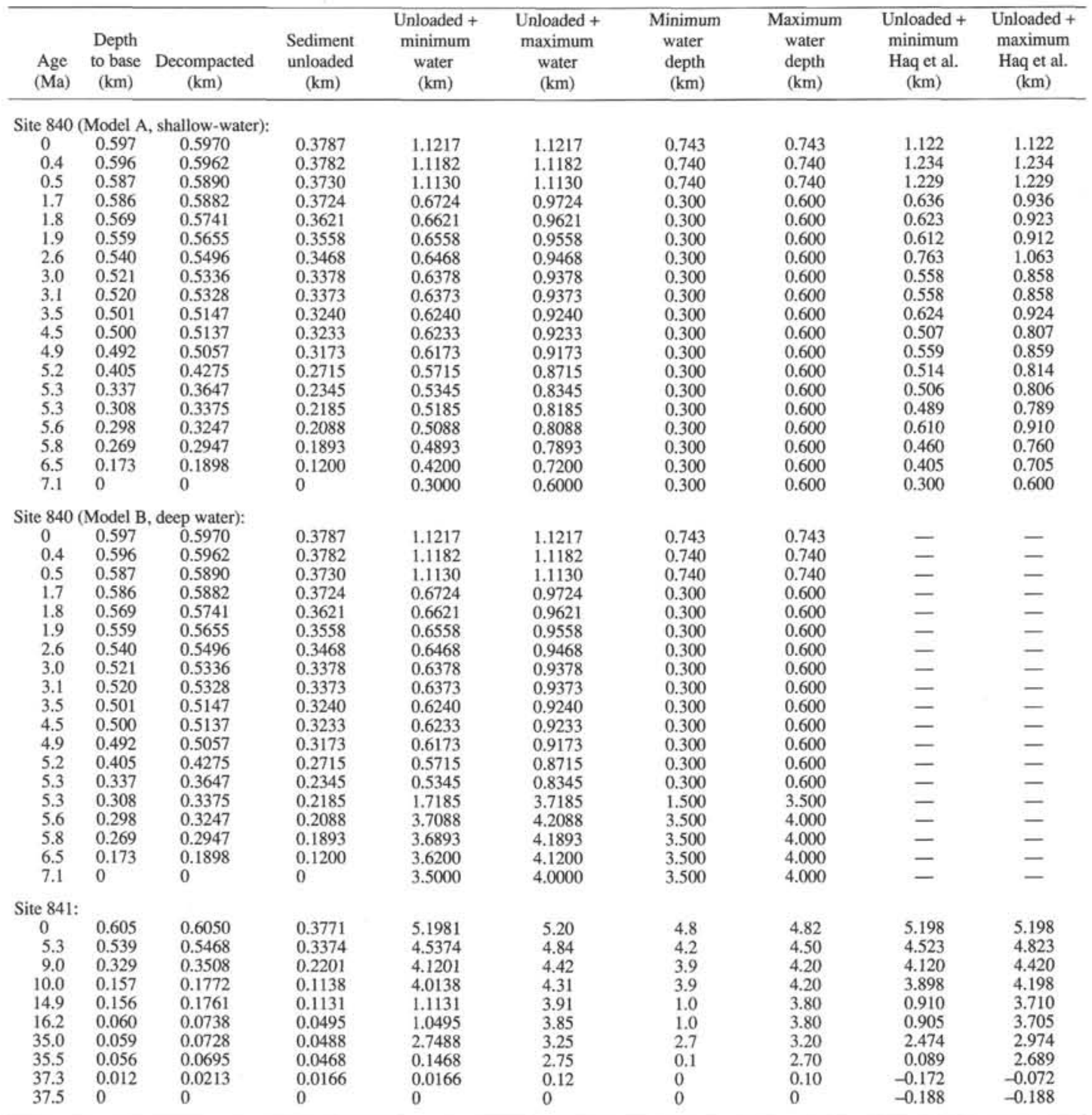

Note: Two models for Site 840 are shown, the first with approximately constant moderate water depths, the second with increased water depths in the late Miocene. 
Table 3. Calculated basement subsidence rates for Sites 840 and 841 .

\begin{tabular}{|c|c|c|c|}
\hline $\begin{array}{l}\text { Age } \\
\text { (Ma) }\end{array}$ & $\begin{array}{l}\text { Sediment unloaded } \\
\text { subsidence rate } \\
(\mathrm{m} / \mathrm{m} . \mathrm{y} .)\end{array}$ & $\begin{array}{l}\text { Age } \\
(\mathrm{Ma})\end{array}$ & $\begin{array}{l}\text { Sediment unloaded } \\
\text { subsidence rate } \\
(\mathrm{m} / \mathrm{m} . \mathrm{y} .)\end{array}$ \\
\hline Site 840 : & & 5.59 & 32.08 \\
\hline 0 & 1.42 & 5.60 & 97.69 \\
\hline 0.39 & 1.42 & 5.79 & 97.69 \\
\hline 0.40 & 51.91 & 5.80 & 99.03 \\
\hline 0.49 & 51.91 & 6.49 & 99.03 \\
\hline 0.50 & 0.49 & 6.50 & 199.95 \\
\hline 1.69 & 0.49 & 7.09 & 199.95 \\
\hline 1.70 & 102.79 & 7.10 & 0 \\
\hline 1.79 & 102.79 & & \\
\hline 1.80 & 63.33 & Site 841: & \\
\hline 1.89 & 63.33 & 0 & 7.49 \\
\hline 1.90 & 11.96 & 5.29 & 7.49 \\
\hline 2.64 & 11.96 & 5.30 & 31.71 \\
\hline 2.65 & 25.71 & 8.99 & 31.71 \\
\hline 2.99 & 25.71 & 9.00 & 106.33 \\
\hline 3.00 & 4.74 & 9.99 & 106.33 \\
\hline 3.09 & 4.74 & 10.00 & 0.13 \\
\hline 3.10 & 33.41 & 14.89 & 0.13 \\
\hline 3.49 & 33.41 & 14.90 & 48.94 \\
\hline 3.50 & 0.73 & 16.19 & 48.94 \\
\hline 4.49 & 0.73 & 16.20 & 0.04 \\
\hline 4.50 & 14.81 & 34.99 & 0.04 \\
\hline 4.89 & 14.81 & 35.00 & 4.08 \\
\hline 4.90 & 152.80 & 35.49 & 4.08 \\
\hline 5.19 & 152.80 & 35.50 & 16.78 \\
\hline 5.20 & 739.64 & 37.29 & 16.78 \\
\hline 5.24 & 739.64 & 37.30 & 82.85 \\
\hline 5.25 & 321.17 & 37.49 & 82.85 \\
\hline 5.29 & 321.17 & 37.50 & 0 \\
\hline 5.30 & 32.08 & & \\
\hline
\end{tabular}

lation rates at $5.30 \mathrm{Ma}$. Following the strong tectonic subsidence initiated at $5.30 \mathrm{Ma}$, Model A (Fig. 5B) further shows a gradual subsidence history up to the present day, presumably related to thermal cooling and subsidence of the basin margins following arc rifting.

Figure 5C shows the calculated subsidence history for Model B. In this case, a very strong uplift occurs immediately before $5.30 \mathrm{Ma}$, when the model predicts a shallowing of the water depth from $3500-4000 \mathrm{~m}$ to approximately $600 \mathrm{~m}$. Following this uplift, the platform undergoes a gradual subsidence to the present. This subsidence pattern is surprising in two ways. First, although uplift along the flanks of a rift can be significant, the magnitude proposed is very high (2-3 km). This is in stark contrast to the very small amount of post-rift subsidence. If this uplift was truly related to rifting, then the amount of extension would have been high. In such a case, a large thermal cooling and subsidence episode should characterize the postrift history. Collision of the Louisville Seamount Chain is unable to account for the large uplift or the lack of post-rift subsidence, as plate motion calculations suggest that it would have collided with the trench adjacent to Site 840 at approximately 0.5 Ma (Dupont and Herzer, 1985), too late to have affected the subsidence patterns. The obvious discrepancy in calculated pre-rift uplift and post-rift subsidence raises further doubts as to the validity of the Model B water depths. A second point of interest comes in a comparison of the uplift event with the subsidence curves generated from oil wells on Tongatapu (Packham, 1985). Because Tongatapu lies a short distance from Site 840 along the strike of the Tonga platform, the two sites might be expected to share similar subsidence histories. Instead, Packham (1985) indicates rapid subsidence at $5.30 \mathrm{Ma}$, similar to the Model A subsidence curves. Although Packham does show some uplift of the Tonga platform, he considers this to be of small magnitude (approximately 100 $\mathrm{m})$ and of Pliocene-Pleistocene age.

Figure 5D shows decompacted subsidence curves for Site 840, constructed using the shallow paleowater depths (Model A) and, in addition, a correction for fluctuations in eustatic sea level according to the curve of Haq et al. (1987). Two significant changes can be seen in the form of the curves. First, the corrected curve no longer shows a marked increase in the rate of tectonic subsidence at 5.3 Ma. Instead, the predicted subsidence is one marked by a steady descent, punctuated by rapid, short-lived uplifts and subsidence events of significant magnitude (150-200 m). Such erratic jumps in the tectonic subsidence of the basement do not correlate with known tectonism along the arc and are not readily compatible with current theory about extensional tectonics (e.g., White and McKenzie, 1988).

Both Models A and B predict a pulse of rapid subsidence from 1.7 Ma to the present, but only in the case of the subsidence curve calculated for the shallowest paleowater depth correction $(300 \mathrm{~m})$. This is a feature not shared by the deeper water depth estimate. This aspect of the shallower water subsidence curves, the large magnitude of the subsidence, and the apparent lack of any change in sedimentary facies suggest that this event is merely the result of poor water depth estimates and that it has no major tectonic significance.

\section{Subsidence History-Site 841}

Figures $8 \mathrm{~A}-8 \mathrm{C}$ illustrate the subsidence curves calculated for Site 841. Again, the curves show the decompacted and sediment unloaded curves (Fig. 8A), as well as the two curves for sediment decompaction and paleowater depth corrections (Fig. 8B). The subsidence pattern is marked by an initial burst of rapid subsidence dating from $35.5 \mathrm{Ma}$, which is responsible for the subsidence of the site to within the lysocline by $35.0 \mathrm{Ma}$, as described in the paleowater depth discussion. Following this event, subsidence is more poorly constrained. As the depth of the CCD and lysocline fall markedly between the start and end of the Oligocene-Miocene hiatus (van Andel, 1975), the deposition of middle Miocene sediments above the lysocline may be explained by either a gradual subsidence, a rapid uplift, or some intermediate change. Structural evidence for a gradual tilting of Site 841 (MacLeod, this volume) during much its history suggests that little or no uplift occurred during the hiatus. This favors the maximum water-depth estimate and suggests that there is little increase in tectonic subsidence at $16.2 \mathrm{Ma}$, despite the influx of coarse clastic sediments. Decompacted subsidence curves (Figs. 7B and 8A) suggest a third pulse of subsidence related to another cycle of sedimentation, dating from $10.0 \mathrm{Ma}$. This event is not so clear when paleowater depth is corrected for, although a mild steepening of the maximum water-depth curve is noted. At these extreme water depths ( $>3900 \mathrm{~m}$ ), accuracy is hard to achieve, which may account for the difficulty in identifying this third subsidence event in the corrected curves. Alternatively, the increased rate of sedimentation may not reflect a change in tectonic subsidence. Interestingly, although Packham (1985) does not recognize this event in all his wells on Tongatapu, an increase in the subsidence curve at $10.0 \mathrm{Ma}$ is recognized in some cases. Since $10.0 \mathrm{Ma}$, gradual subsidence has characterized development of Site 841.

Figure 8C shows the decompacted and sediment unloaded curves with correction for paleowater depths and fluctuations in eustatic sea level (Haq et al., 1987). The curve appears very similar in form to the curve with no eustatic correction. This reflects the great magnitude of paleowater depths at Site 841. In deep water, eustatic fluctuations will only cause a small difference in the total depth, in contrast to the dramatic changes recorded in shelf and platform areas.

\section{DISCUSSION}

The foregoing description of the sedimentary and subsidence evolution of the Tonga platform and forearc basin show that since the late Eocene, the active margin of the Indo-Australian Plate has undergone a series of major tectonic disruptions that are recorded in sediments recovered and logged at Sites 840 and 841 . Four major events were recognized. The youngest, dated at $5.30 \mathrm{Ma}$, is recorded only at Site 840 as a rapid influx of coarse volcaniclastic debris and as a jump in the subsidence rate from 32.0 to $321.0 \mathrm{~m} / \mathrm{m}$.y. This event is not recognized at Site 841 , but this may be merely the result of the ambient water depth of this locality at this time. In contrast to Site 840 , where sedimentation kept pace with subsidence, Site 841 is 
A

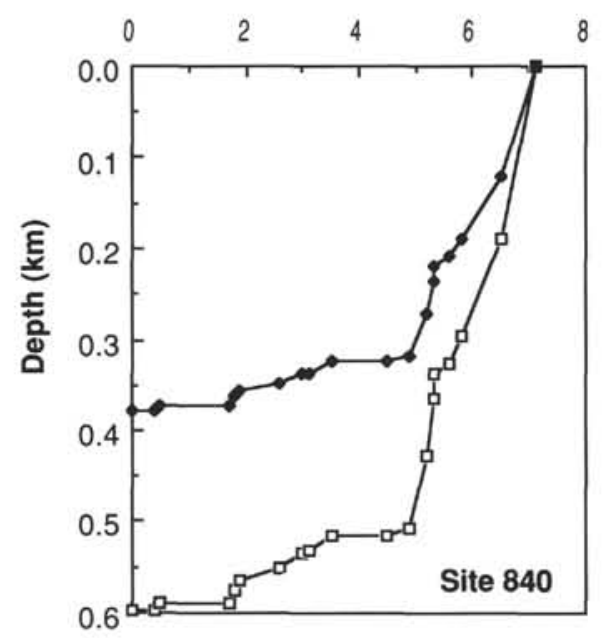

$\longrightarrow$ Decompacted and uncorrected

$\longrightarrow$ Sediment unloaded $/ \mathrm{km}$

B

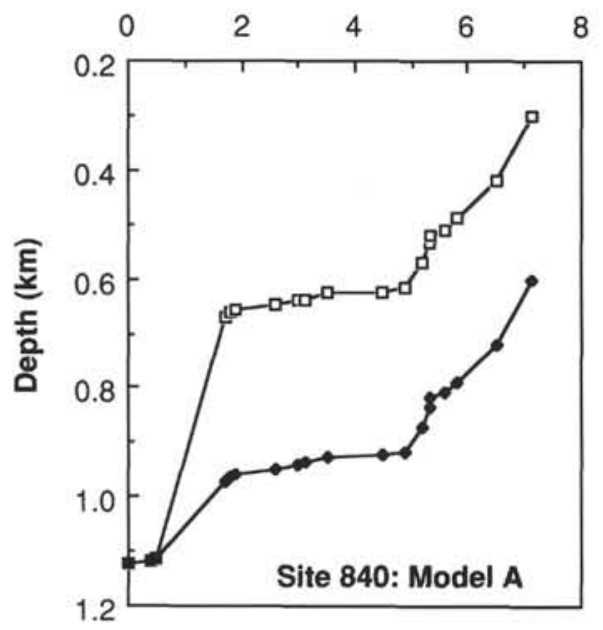

C Age (Ma)

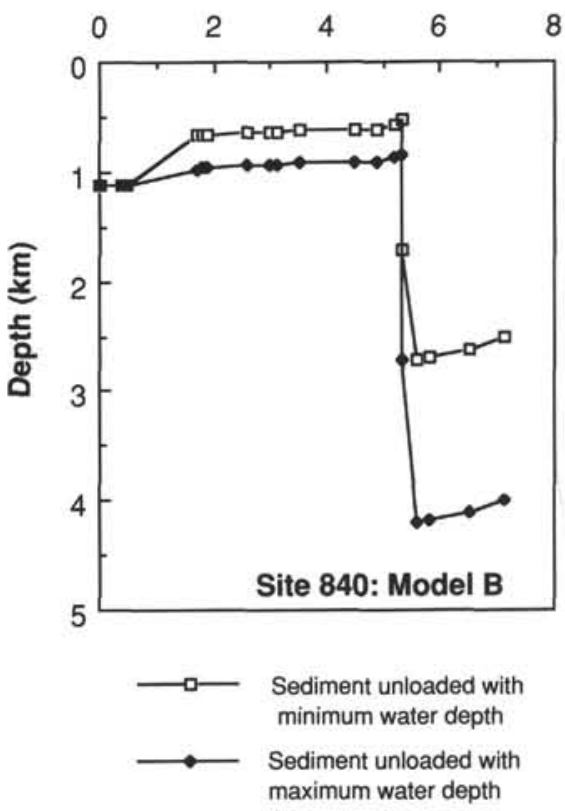

D

Age (Ma)

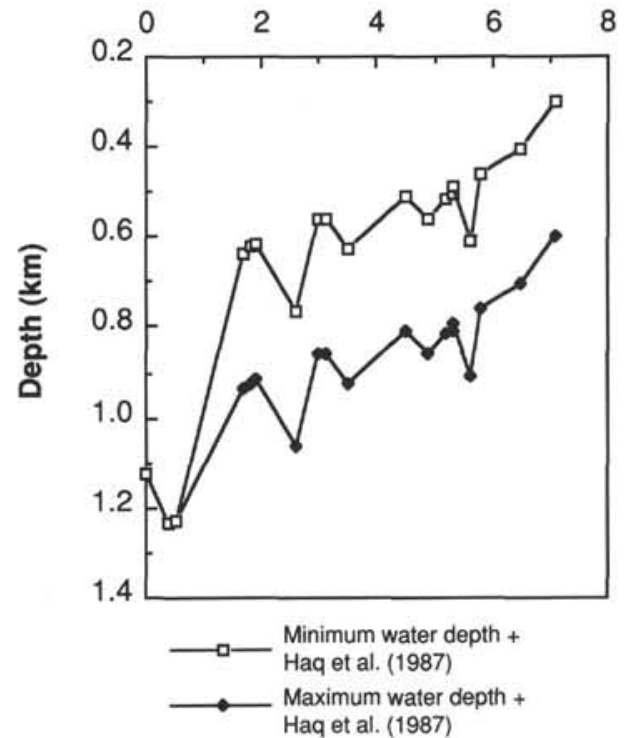

Figure 5. A. Decompacted and water-unloaded subsidence curves calculated for the sedimentary section drilled at Site 840 (Tonga platform), showing the subsidence of the basement relative to present sea levels. No correction is given for paleowater depth. The sediment unloaded curve reflects basement subsidence, because sedimentation has kept pace with subsidence at Site 840 . B. Curves with correction for paleowater depths using Model A (constant moderate water depths). C. Model B (increased water depths during the late Miocene). D. Curves with correction for paleowater depths (Model A) and sea-level variation (Haq et al., 1987).

sediment starved, so that tectonically driven basement subsidence is principally recognized as an increase in water depth rather than as thick packages of sediment. The weight of the paleowater depth evidence and comparisons of the two models of Tongan platform evolution strongly indicate that subsidence and influx of sediment at Site 840 are a result of active normal faulting at $5.30 \mathrm{Ma}$. This correlates approximately with the 5.25 Ma date for rifting of the Lau Basin (Fig. 9) derived from the magnetostratigraphy of sediments overlying the basaltic basement at Site 834 in the western Lau Basin (Parson, Hawkins, Allan, et al., 1992).

A second pulse in sedimentation and possible accompanying subsidence at $10.0 \mathrm{Ma}$ was only recognized at Site 841 . Although drilling at Site 840 did not penetrate far enough to recover sediments as old as $10.0 \mathrm{Ma}$, rapid subsidence and sediment accumulation recorded at the bottom of the sequence at Site 840 (i.e., $7.0 \mathrm{Ma}$ ) could correlate with rapid subsidence calculated for Site 841 from $10.0 \mathrm{Ma}$ 

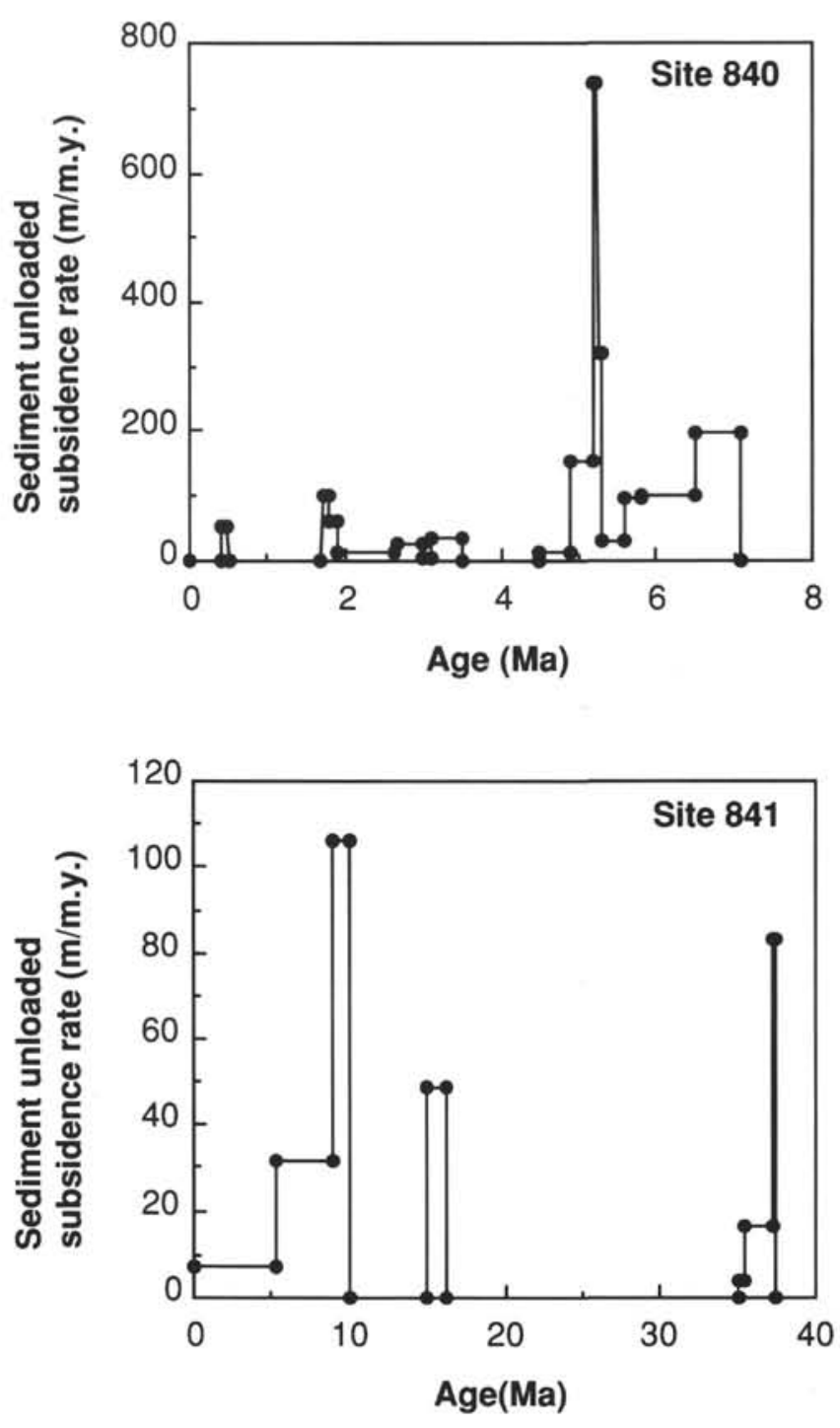

Figure 6. Calculated subsidence rate histories for Sites 840 and 841.

onward. Tectonic disruption of the arc and forearc at this time can be correlated to the regional readjustment of the plate boundary geometry following reinitiation of subduction along the New Hebrides section of the island arc at $10.0 \mathrm{Ma}$ (Moberly, 1971). Subduction in this region underwent a polarity reversal caused by the collision of the Ontong-Java Plateau with the original Vitiaz Trench from approximately $25.0 \mathrm{Ma}$ onward. Although this collision caused local compression in the New Hebrides (Gill et al., 1984), in the Tonga Arc the event is marked by extension and rotation of the original arc, with synchronous rifting and spreading in the North Fiji Basin (Auzende et al., 1988).

The third subsidence and sedimentation event, recognized at Site 841 alone, dates from $16.2 \mathrm{Ma}$ and does not readily correlate with a known regional tectonic event. The period in question was one marked by steady-state subduction along the original Vitiaz/Tonga Trench. Spreading in the South Fiji Basin had finished by the end of the Oligocene (Weissel and Watts, 1975), approximately 25.0 Ma, and so cannot be related to this event. As discussed above, the magnitude of this event is debatable, depending on the amount of uplift that Site 841 experienced during the period of unconformity (35.0-16.2 Ma). If this was small, or if subsidence had continued, as suggested by the structural data of MacLeod (this volume), then the tectonic basement subsidence related to the deposition of the volcaniclastic mass flows
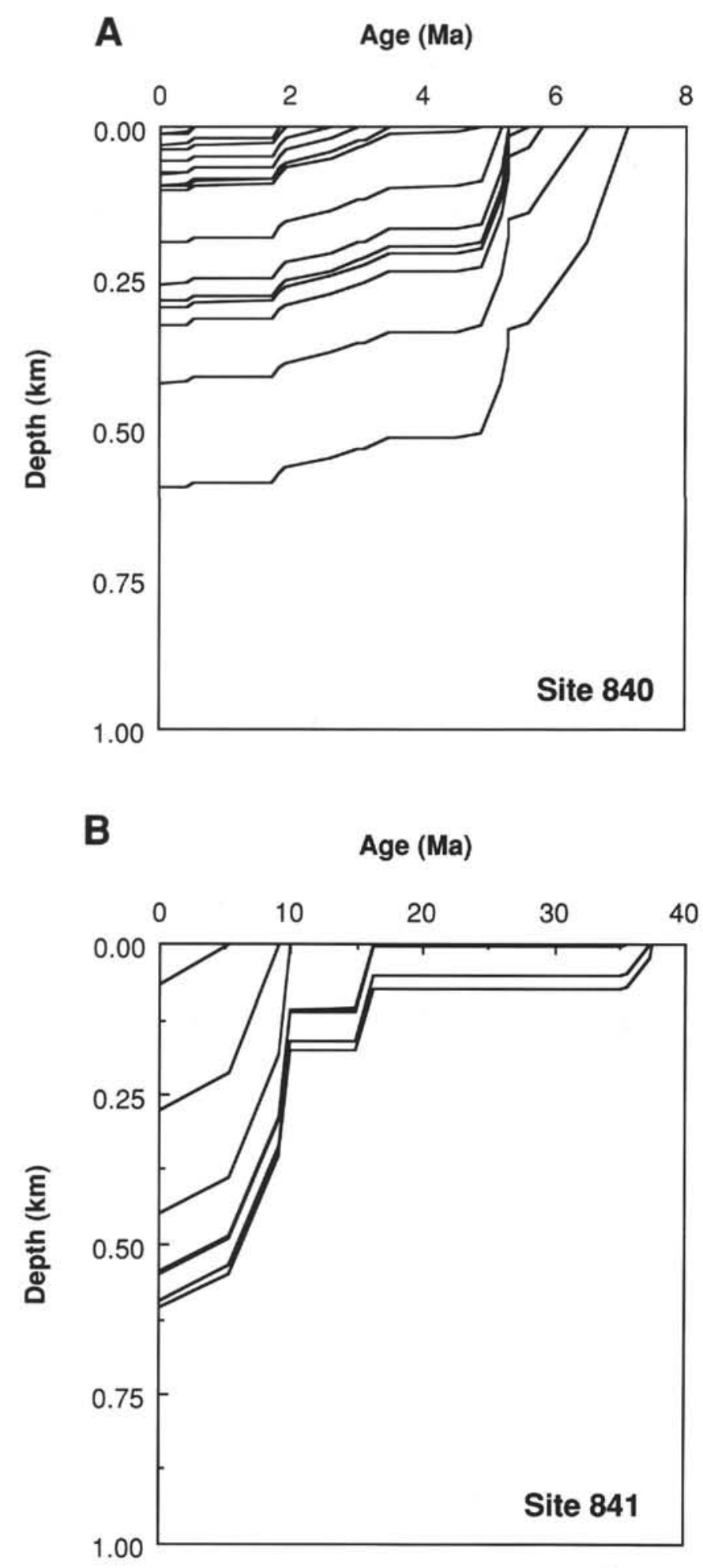

Figure 7. Sedimentation/time diagrams illustrating the progressive sediment accumulation history of Sites 840 and 841 . Diagrams show the effects of sediment compaction, but they are uncorrected for changes in eustatic sea level.

would also be small. It seems likely that any subsidence dating from 16.2 Ma at Site 841 took place as a result of local extensional faulting related to the gravitational rollback of the subducting slab at the trench. The old cold lithosphere being subducted (calculated to be of Jurassic age) would have been gravitationally unstable, with the result that the hinge of the subducting plate would have migrated ocean- 

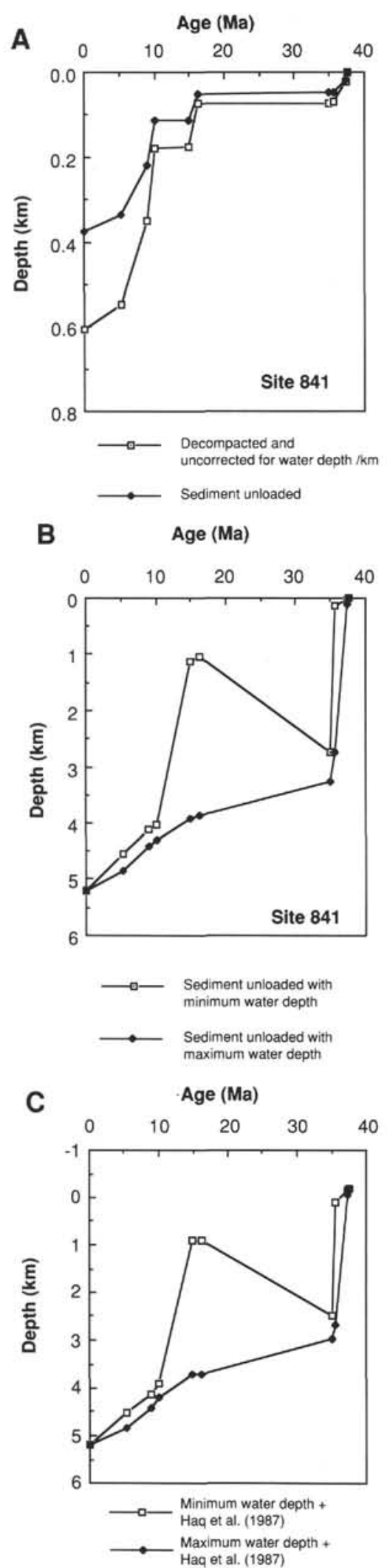

Figure 8. A. Decompacted and water-unloaded subsidence curves calculated for the sedimentary section drilled at Site 841 (Tonga forearc). Sediment unloaded curve does not reflect basement subsidence because of sedimentation being outstripped by subsidence. B. Curve with correction for paleowater depths. C. Curve with correction for paleowater depths and fluctuations in eustatic sea level (Haq et al., 1987). ward, away from the trench (Turcotte and Schubert, 1982; Fig. 9). This hinge migration would, in turn, cause extension in the overriding plate, which would lead to subsidence and faulting-related sedimentation along the frontal edge of the forearc. In effect, subsidence at Site 841 dating from 16.2 Ma can be related to migration of a zone of extensional deformation away from the trench into the plate, in much the same way as the present Tonga forearc is in extension. In any case, normal faulting in the forearc close to Site 841 could readily explain the influx of coarse clastic material, without necessitating a major increase in basement subsidence.

The oldest subsidence event recognized at Site 841 dates from 35.5 Ma. This readily correlates with the onset of rifting in the South Fiji Basin (Weissel and Watts, 1975; Fig. 9), and attendant extension and subsidence of the original Vitiaz Arc.

\section{Tectonic Vs. Eustatic Control?}

Although it has been demonstrated that the fluctuations in the eustatic sea level proposed by Haq et al. (1987) cannot account for all the subsidence at either Site 840 or 841 , evidence does exist that eustatic sea level exerts a degree of control over sedimentation. Previous work on the relationship between sea level and sedimentation has tended to analyze sedimentary basins in extensional or passive margin settings (e.g., Haq et al., 1987). More recently, however, the role of eustacy in active margin basins has been examined. Carter et al. (1991), working on the Cenozoic of the New Zealand continental margin, concluded that sea-level variations in the area did not correlate well with the predictions of Haq et al. (1987). They did, however, consider that sea level had been the principle control on sedimentation and that the tectonics of the adjoining hinterland played only a minor role in the sedimentary evolution of the continental margin. In contrast, Fortuin and De Smet (1991) considered tectonic activity in the Banda Arc of Indonesia to be the dominant control on sedimentation and that the eustatic component in shaping the forearc was strongly masked, making the recognition of sea-level variations difficult. Because each subsidence event at Sites 840 and 841 has been correlated to a regional tectonic event, this interpretation will now be checked against predicted sea-level fluctuations.

In the case of the influx of sediment at 5.30 Ma at Site 840 (dated within foraminifer Subzone N17B after the appearance of Globigerinoides conglobatus), correlation with events on the Haq et al. (1987) curve is difficult. A fall in eustatic sea level, which might have caused an influx of clastic material, does occur at $5.50 \mathrm{Ma}$ (nannofossil Subzone CN9b; foraminifer Subzone N17B before Globigerinoides conglobatus). In contrast, the minimum age of rifting of the Lau Basin, derived from the oldest dated sediment in the Lau Basin (Site 834 ) is $5.20 \mathrm{Ma}$ (nannofossil Subzone CN10a; foraminifer Zone $\mathrm{N} 18$ ). If tectonics were controlling the sedimentation, then the small time delay between extensional faulting at Site 840 and the first new backarc basin crust is entirely to be expected, as arc rifting is not an instantaneous process. However, the delay between sea-level fall at $5.50 \mathrm{Ma}$ and sediment influx at $5.30 \mathrm{Ma}$ is more difficult to explain if eustacy was the controlling factor. Furthermore, if the fall in eustatic sea level was the primary cause of the clastic pulse at $5.30 \mathrm{Ma}$, then the lack of similar sedimentary responses after falls in the eustatic sea levels of equal magnitude between $5.30 \mathrm{Ma}$ and the present (4.20, $3.80,2.80,1.80$, and $0.80 \mathrm{Ma}$ ) is rather enigmatic.

In contrast, the sedimentary event dated as $10.0 \mathrm{Ma}$ at Site 841 (nannofossil Zone CN7; foraminifer Zone N18) appears to be more readily correlated with eustatic sea-level fall. Although the Haq et al. (1987) curve predicts a fall of $>100 \mathrm{~m}$ at $10.5 \mathrm{Ma}$, the initiation of subduction along the New Hebrides Trench is rather poorly constrained at approximately $10.0 \mathrm{Ma}$ and cannot be tied in precisely. The good correlation between the decrease in eustatic sea level and clastic influx strongly suggests that a decrease in sea level did play an important role in sediment supply at this time. However, a tectonic component can also be inferred because of the continued sediment 
A

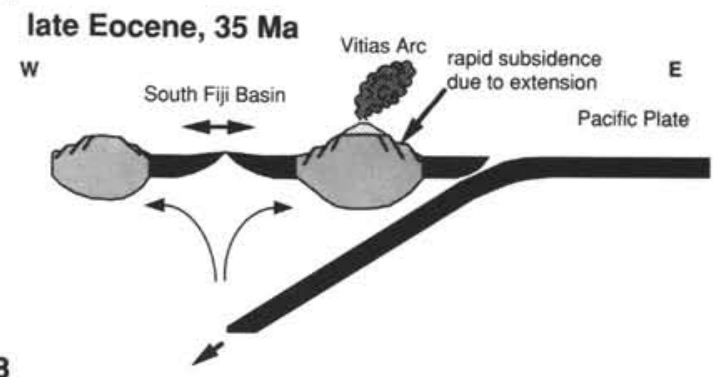

mid Miocene, $16 \mathrm{Ma}$ - tectonic erosion

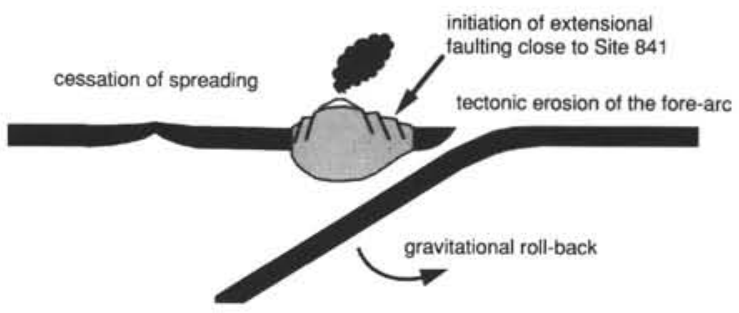

C

late Miocene, $10 \mathrm{Ma}$ - subduction polarity reversal in New Hebrides fall in eustatic sealevel

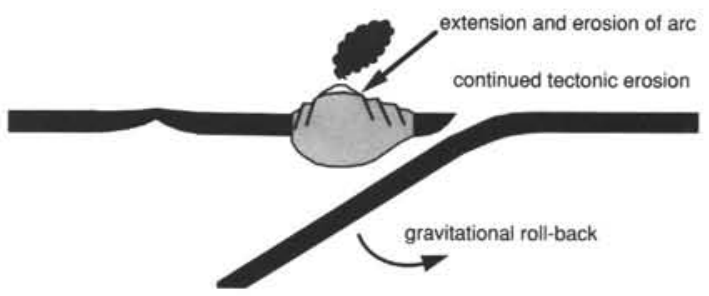

D late Miocene, $5.6 \mathrm{Ma}$ - extension of the arc

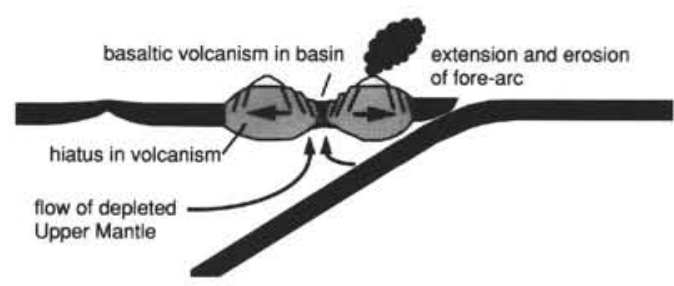

E late Pleistocene, $0.5 \mathrm{Ma}$ - Spreading starts on Eastern Lau Centre.

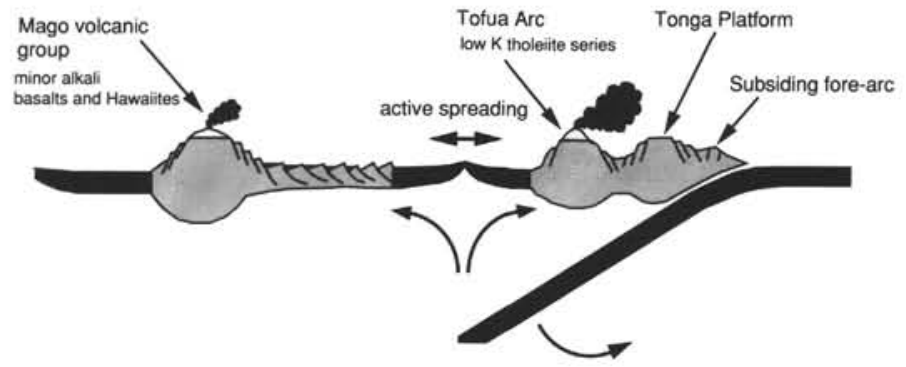

Figure 9. Tectonic cartoons showing the proposed tectonic evolution of the Tonga arc system from the late Eocene to the present.

supply and subsidence between 10.0 and $7.0 \mathrm{Ma}$. The predicted sharp rise in sea level shortly after the $10.5 \mathrm{Ma}$ eustatic minimum might be expected to curtail the clastic influx. Not only was this not observed, but continued basement subsidence over the same time span at Site 841 (and especially at Site 840 after 7.0 Ma) suggests that the forearc was affected by ongoing tectonic rifting. Thus, the 10.0 Ma sedimentary event is most likely to be the result of a combination of tectonic activity and eustatic sea-level fluctuation.

The subsidence recorded at $16.2 \mathrm{Ma}$ at Site 841 occurs close to predicted declines in eustatic sea level at 15.5 and $16.5 \mathrm{Ma}$ (Haq et al., 1987). Correlation with either of these events is possible, but subsequent rises in sea level shortly after each minimum raise questions as to their ability to produce a long-lived, upward-fining sequence. Looking at the long-term eustatic variations, Haq et al. (1987) predict that sea level underwent a progressive fall (second-order cycle) between 16.2 and $10.0 \mathrm{Ma}$. It is possible that this fall might have driven deposition of the observed sequence. As far as the influence of tectonics is concerned, the degree to which the forearc was affected by tectonic activity at $16.2 \mathrm{Ma}$ depends on which paleowater depth estimate is considered to be the more accurate. Estimates for the increase in paleowater depth at this time range from only 100 to $3200 \mathrm{~m}$, compared with Haq et al.'s (1987) prediction of a fall and rise in sea level of only $75 \mathrm{~m}$. Thus, if the lower value is preferred, as suggested by the structural data of MacLeod (this volume), then the amount of tectonically driven subsidence would have been quite modest.

Sedimentation in the late Eocene and early Oligocene shows little evidence for eustatic control. Increases in paleowater depth by $2700-$
$3200 \mathrm{~m}$ between 37.3 and 35.5 Ma can only be accounted for by tectonically driven subsidence. Similarly, the major unconformity dating from 35.0 to $16.2 \mathrm{Ma}$ is probably not the result of changes in eustatic sea level, as it spans numerous phases of sea-level rise and fall.

It is possible, therefore, to conclude that sedimentation at Sites 840 and 841 shows some evidence of eustatic influence, although superimposed on a dominant tectonic background.

\section{CONCLUSIONS}

A number of important conclusions can be drawn from consideration of the subsidence and sedimentary history of the Tonga Arc at Sites 840 and 841 . Extension of the original Miocene arc during formation of the Lau Basin caused rapid tectonic subsidence and fault scarp-derived volcaniclastic conglomerate and sand deposition. Interestingly, however, a similar backarc basin-forming event during the early Oligocene (South Fiji Basin; Fig. 9) seems to have produced a rather different sedimentary response while also causing a rapid burst of subsidence. The fine-grained nature of the sediment deposited in the early Oligocene (compared to the volcaniclastic breccias of the late Miocene) may reflect the relatively distal position of Site 841 with respect to the arc during the earlier event. Alternatively, rapid drowning and extinction of the volcanic arc at the time of basin rifting would also minimize the amount of volcanic debris eroded and thus produce the sequence observed. This scenario would be easier to achieve if the arc were smaller in the Oligocene than in the Miocene. Because subduction along the Vitiaz Arc is thought to date from approximately $45.0 \mathrm{Ma}$ (middle Eocene; Gill, 1976), it seems likely 
that the size of the Oligocene arc would be smaller than an arc generated over a longer time span in a mature active margin setting.

An interesting comparison may also be drawn between the collision of the Ontong-Java Plateau and the subduction of the Louisville Seamount chain (Fig. 1). In the case of the Ontong-Java Plateau, collision with the trench resulted in a dramatic series of tectonic events: arc fragmentation and extension, with subduction polarity reversal in the Solomon Islands. In the case of the collision of the Louisville Ridge with the trench, compressional and extensional deformation occurs, as well as localized slumping and redeposition of sediment in the forearc basin. However, outside the vicinity of ridge-forearc collision, the effect on the arc seems to have been slight. While the sediments at Site 841 were of a deep-water facies, too deep and too poorly dated to detect a change in subsidence rate during the passage of the ridge, those at Site 840 might be expected to identify such an event. The fact that there is only mild disruption to a well-dated and constrained subsidence curve suggests that subduction of seamount ridges along non-accretionary plate margins only seems to affect that margin in the most trenchward part of the forearc. However, uplift or subsidence within the limits of the paleowater depth estimates at Site $840(300-600 \mathrm{~m})$ will of course not be visible. This result is in conflict with the conclusions of Dupont and Herzer (1985) and Tappin et al. (1992), who suggested major doming and faulting of the Tonga Platform due to subduction of the Louisville Ridge. This study does not support major deformation of the plate margin away from the point of collision of the Louisville Seamount Chain and the Tonga forearc. Possible minor subsidence events detected at Site 840 that may be attributable to the passage of the Louisville Ridge cannot include the jump in the subsidence rate to $91.26 \mathrm{~m} / \mathrm{m} . y$. at $1.7 \mathrm{Ma}$ (Fig. 6A), because Dupont and Herzer (1985) calculate that the ridge was at that time still north of Tongatapu. Instead, an increase in subsidence rate to $51.27 \mathrm{~m} / \mathrm{m}$.y., dated at $0.5 \mathrm{Ma}$ (Fig. 6A), would instead seem to coincide with ridge-trench collision in the area of Site 840. Compared to the subsidence related to earlier tectonic events, the effect of the Louisville Ridge on the Tonga Platform is minor.

The contrast between the collision of the Ontong-Java Plateau and the Louisville Ridge indicates that size may be critically important in assessing the result of the collision of intra-oceanic features with an active margin. Deformation and uplift of the active margin caused by a collision of the d'Entrecasteaux Ridge with the New Hebrides Trench (Collot, Greene, Stokking, et al., 1992) suggests that major oceanic ridges, not much larger than the Louisville Ridge, can have a significant impact on the tectonic evolution of active plate margins.

Finally, it is noteworthy that neither of the subsidence curves at Site 840 or 841 indicates any fluctuation in the subsidence rate or sedimentation at the time of the regional unconformity (seismic "A-Horizon" of Austin et al., 1989). This raises the question of whether the correct depth has been allocated to the A-Horizon and, if so, exactly to what this level corresponds. Assuming that the reflector identified by Austin et al. (1989) truly lies at 383.0 mbsf, it seems unlikely that this can have any major regional tectonic significance; instead, it may merely correspond to a short-lived depositional hiatus during the late Miocene.

In summary, the sedimentary sequences at Sites 840 and 841 on the Tonga Forearc suggest that periods of rapid tectonic subsidence and associated influxes of coarse clastic debris correlate with periods of arc rifting and backarc basin formation (i.e., the South Fiji and Lau basins). Evidence is present that suggests an increase in tectonic subsidence as a result of forearc extension from the initiation of subduction in the New Hebrides. Gradual subsidence is caused by the continuous process of tectonic erosion and extension of the more trenchward portions of the forearc. Fluctuations in eustatic sea level have played a noticeable but subsidiary role in controlling the input of sediment on to the forearc. Collision of the Louisville Seamount Chain with the forearc caused deformation close to the trench. However, uplift of the adjacent Tonga platform appears to be modest and is limited to a maximum of $300 \mathrm{~m}$.

\section{ACKNOWLEDGMENTS}

Jonathan Turner and Roger Scrutton are thanked for their advice in producing the subsidence curves. John Waldron is thanked for his help in the use of computer-drawn sedimentary logs. Robin Reynolds and all the people at the Borehole Research Group at Lamont-Doherty Geological Observatory are thanked for their help in my initiation into the interpretation of FMS data. Phil Weaver, David McDonald, and Jamie Austin are thanked for their reviews, which helped improve this paper greatly. This work was undertaken during tenure of a British Petroleum/Royal Society of Edinburgh postdoctoral fellowship.

\section{REFERENCES}

Austin, J., Taylor, F.W., and Cagle, C.D., 1989. Seismic stratigraphy of the Central Tonga Ridge. Mar. Pet. Geol., 6:71-92.

Auzende, J.-M., Lafoy, Y., and Marsset, B., 1988. Recent geodynamic evolution of the north Fiji basin (southwest Pacific). Geology, 16:925-929.

Berger, W.H., and Winterer, E.L., 1974. Plate stratigraphy and the fluctuating carbonate line. In Hsü, K.J., and Jenkyns, H.C. (Eds.), Pelagic Sediments on Land and Under the Sea. Spec. Publ. Int. Assoc. Sedimentol., 1:11-48

Carter, R.M., Abbott, S.T., Fulthorpe, C.S., Haywick, D.W., and Henderson, R.A., 1991. In McDonald, D.I.M. (Ed.), Sedimentation, Tectonics and Eustacy. Spec. Publ. Int. Assoc. Sedimentol., 12:41-65.

Collot, J.-Y., Greene, H.G., Stokking, L.B., et al., 1991. Proc. ODP, Init. Repts., 134: College Station, TX (Ocean Drilling Program).

Condon, P., 1988. Seismic stratigraphy and distribution of Palaeogene sediments west and east of Shetland [Ph.D. thesis]. Univ. of Edinburgh, Scotland.

Dupont, J., and Herzer, R.H., 1985. Effect of subduction of the Louisville Ridge on the structure and morphology of the Tonga arc. In Scholl, D.W., and Vallier, T.L. (Eds.), Geology and Offshore Resources of Pacific Island Arcs-Tonga Region. Circum-Pac. Counc. Energy Mineral Resour., Earth Sci. Ser., 2:323-332.

Ekdale, A.A., Bromley, R.G., and Pemberton, S.G. (Eds.), 1984. Ichnology: Trace Fossils in Sedimentology and Stratigraphy. SEPM Short Course, 15.

Fortuin, A.R., and De Smet, M.E.M., 1991. Rates and magnitudes of the late Cenozoic vertical movements in the Indonesian Banda Arc and the distinction of eustatic effects. In McDonald, D.I.M. (Ed.), Sedimentation, Tectonics and Eustacy. Spec. Publ. Int. Assoc. Sedimentol,, 12:79-89.

Gill, J.B., 1976. Composition and age of Lau basin and ridge volcanic rocks: implications for evolution of an interarc basin and remnant arc. Geol. Soc. Am. Bull., 87:1384-1395.

Gill, J.B., Stork, A.L., and Whelan, P.M., 1984. Volcanism accompanying backarc basin development in the Southwest Pacific. Tectonophysics, 102:207-224.

Hallam, A., 1984. Pre-Quaternary sea level change. Annu. Rev. Earth Planet. Sci., 12:205-243.

Haq, B.U., Hardenbol, J., and Vail, P.R., 1987. Chronology of fluctuating sea levels since the Triassic. Science, 235:1156-1167.

Harker, S.D., McGann, G.J., Bourke, L.T., and Adams, J.T., 1990. Methodology of formation micro-scanner image interpretation in Claymore and Scapa Fields (North Sea). In Hurst, A., Lovell, M.A., and Morton, A.C. (Eds.), Geological Applications of Wireline Logs. Geol. Soc. Spec. Publ. London, 48:13-23.

Karig, D.E., 1970. Ridges and basins of the Tonga-Kermadec island arc system. J. Geophys. Res., 75:239-254.

McKenzie, D.P., 1978. Some remarks on the development of sedimentary basins. Earth Planet. Sci. Lett., 40:25-32.

Moberly, R., 1971. Youthful oceanic lithosphere of marginal isles, western Pacific. Proc. 12th Pac. Sci. Congr., Canberra.

Packham, G.H., 1985. Vertical tectonics on the Tonga Ridge from the Tongatapu oil exploration wells. In Scholl, D.W., and Vallier, T.L. (Eds.), Geology and Offshore Resources of Pacific Island Arcs-Tonga Region. Circum-Pac. Counc. Energy Miner. Resour., Earth Sci. Ser., 2:291-300.

Parson, L., Hawkins, J., Allan, J., et al., 1992. Proc. ODP, Init. Repts., 135: College Station, TX (Ocean Drilling Program).

\footnotetext{
-Abbreviations for names of organizations and publication titles in ODP reference list follow the style given in Chemical Abstracts Service Source Index (published by American Chemical Society).
} 
Sclater, J.G., and Christie, P.A.F., 1980. Continental stretching: an explanation of the post-mid-cretaceous subsidence of the central north sea basin. $J$. Geophys. Res., 85:3711-3739.

Seilacher, A., 1963. Kaledonischer Unterban der Irakiden. Neues Jahrb. Geol. Palaeontol., 10:527-542.

Serra, O., 1989. Formation MicroScanner Image Interpretation: Houston (Schlumberger Educ. Services).

Shipboard Scientific Party, 1973. Site 207. In Burns, R.E., Andrews, J.E., et al., Init. Repts. DSDP, 21: Washington (U.S. Govt. Printing Office), 197-269.

Tappin, D.R., Herzer, R.H., and Stevenson, A.J., 1992. Structure and history of an oceanic forearc-the Tonga Ridge $22^{\circ}$ to $26^{\circ}$ South. In Ballance, P.F., Herzer, R.H., and Stevenson, A.J. (Eds.), Geology and Resources of Island Arcs, Tonga-Lau-Fiji Region: Berlin (Springer-Verlag).

Tucker, M.E., and Wright, P.V., 1990. Carbonate Sedimentology: Oxford (Blackwell Sci. Publ.).

Turcotte, D.L., and Schubert, G., 1982. Geodynamics: Applications of Continuum Physics to Geological Problems: New York (Wiley).

Underhill, J.R., 1991. Controls on Late Jurassic seismic sequences, Inner Moray Firth, UK North Sea: a critical test of a key segment of Exxon's original global cycle chart. Basin Res., 3:79-98.

Vail, P.R., Mitchum, R.M., and Thompson, S., III, 1977. Seismic stratigraphy and global changes of sea level. Part 2: the depositional sequence as a basic unit for stratigraphic analysis. In Payton, C.E. (Ed), Seismic Stratigraphy-Applications to Hydrocarbon Exploration, AAPG Mem., 26:53-62.

van Andel, T.H., 1975. Mesozoic-Cenozoic calcite compensation depth and the global distribution of calcareous sediments. Earth Planet. Sci. Lett., 26:187-194.

Waldron, J.R., 1991. Litholog: a sedimentary logging program for the Apple Macintosh. Dep. of Geol., St Mary's Univ., Halifax, Nova Scotia, Canada.

Weissel, J.K., and Watts, A.B., 1975. Tectonic complexities in the south Fiji marginal basin. Earth Planet. Sci. Lett., 28:121-126.

White, N., and McKenzie, D.P., 1988. Formation of the Steer's head geometry of sedimentary basins by differential stretching of the crust and mantle. Geology, 26:250-253.

Wise, S.W., 1981. Deep sea drilling in the Antarctic: focus on late Miocene glaciation and applications of smear-slide biostratigraphy. Spec. Publ.Soc. Econ. Paleontol. Mineral., 32:471-487.

Wood, R.J., 1982. Subsidence in the North Sea [Ph.D. thesis]. Cambridge Univ., England.

Date of initial receipt: 29 June 1992

Date of acceptance: 2 February 1993

Ms 135SR-103 